\title{
The acid sulfate zone and the mineral alteration styles of the Roman Puteoli (Neapolitan area, Italy): clues on fluid fracturing progression at the Campi Flegrei volcano
}

\author{
Monica Piochi ${ }^{1}$, Angela Mormone ${ }^{1}$, Harald Strauss ${ }^{2}$, and Giuseppina Balassone ${ }^{3}$ \\ ${ }^{1}$ Osservatorio Vesuviano, Istituto Nazionale di Geofisica e Vulcanologia, Naples, 80124, Italy \\ ${ }^{2}$ Institut für Geologie und Paläontologie, Westfälische Wilhelms-Universität, Münster, 48149, Germany \\ ${ }^{3}$ Dipartimento di Scienze della Terra, dell'Ambiente e delle Risorse, Università Federico II, Naples, 80126, Italy
}

Correspondence: Monica Piochi (monica.piochi@ingv.it)

Received: 13 March 2019 - Discussion started: 8 May 2019

Revised: 27 August 2019 - Accepted: 16 September 2019 - Published: 30 October 2019

\begin{abstract}
Active fumarolic solfataric zones represent important structures of dormant volcanoes, but unlike emitted fluids, their mineralizations are omitted in the usual monitoring activity. This is the case of the Campi Flegrei caldera in Italy, among the most hazardous and best-monitored explosive volcanoes in the world, where the landscape of Puteoli is characterized by an acid sulfate alteration that has been active at least since Roman time. This paper provides temperature, mineralogical, textural, compositional and stable isotope data for those solfataric terrains sampled at the crater and Pisciarelli slope of the Solfatara volcano between 2013 and 2019. Temperatures vary between 40 and $95^{\circ} \mathrm{C}$. Minerals include alunite with grain sizes generally larger than $20 \mu \mathrm{m}$, alunogen, native sulfur, well-ordered kaolinite, and, common at Pisciarelli, pyrite, illite and $\mathrm{NH}_{4}$ sulfates. Sulfate terrains have higher contents of $\mathrm{Ti}, \mathrm{Ba}, \mathrm{Au}, \mathrm{As}, \mathrm{Hg}$ and $\mathrm{Tl}$ relative to their parent substrate. The Pisciarelli slope is anomalous in terms of the presence of $\mathrm{NH}_{4} . \delta^{34} \mathrm{~S}$ values for sulfides and native $\mathrm{S}$ range between $-3.00 \%$ and $0.49 \%$ o and from $-4.42 \%$ to $0.80 \%$, respectively. Sulfates show $\delta^{34} \mathrm{~S}$ and $\delta^{18} \mathrm{O}$ values in the range of $-2.78 \%$ to $2.09 \%$ o and between $4.60 \%$ and $31.33 \%$, respectively. The style of mineralization and the stable isotope geochemistry do produce complex and not completely consistent classifications and genetic constraints. We merge our data with volcanological information, data from exploration drillings and geophysical results. With the conceptual model, we suggest a series of shallow and deep aquifers interconnected like "communicating vessels" through a main fault system that downthrows Solfatara with respect to Pisciarelli. Fluid outflow from the
\end{abstract}

different discrete aquifers hosted in sediments - and possibly bearing organic imprints - is the main dataset that allows determination of the steam-heated environment with a supergene setting superimposed. Supergene conditions and highsulfidation relicts, together with the narrow sulfate alteration zone buried under the youngest volcanic deposits, point to the existence of an evolving paleo-conduit. The data will contribute to monitoring and evaluating the volcanic hazards.

\section{Introduction}

Active solfataric landscapes are among the most peculiar and fascinating environments on the Earth that may be considered as planetary analogues (e.g., White and Hedenquist, 1990; Rye et al., 1992; Lowe et al., 1993; Zillig et al., 1996; Ciniglia et al., 2005; Rye, 2005; Glamoclija et al., 2004; Sgavetti et al., 2008). Their peculiarity arises from the stringent interaction between inorganic (mineral assemblages and geochemistry) and organic (biota) substances under extreme ambient conditions $(\mathrm{pH}$, temperature, salinity, oxygen deficiency, etc.) associated with endogenous degassing (i.e., $\mathrm{H}_{2} \mathrm{O}, \mathrm{CO}_{2}, \mathrm{CH}_{4}, \mathrm{H}_{2} \mathrm{~S}, \mathrm{SO}_{2}, \mathrm{HCl}, \mathrm{HF}$, etc.) and hot water fluid circulation (hydrothermal/geothermal systems) on dormant volcanoes. They allow investigating a variety of processes in the field of geology (i.e., magma and volcano dynamics), biology (i.e., physiological adaptation to environmental stresses and the origin of the life), medicine, astrology and archeology (i.e., thermal bath and antibacterial applica- 
tions), with possible future medical and biotechnological applications (e.g., Notomista et al., 2015; Politi et al., 2015; Photos-Jones et al., 2016).

The Solfatara volcano (Campi Flegrei, CF, Italy; Fig. 1a) is perhaps the most famous and hazardous geothermal solfataric setting in the world (e.g., Rittmann, 1950; Rosi and Sbrana, 1987; De Vivo et al., 1989; Barberi et al., 1984; Piochi et al., 2014) with exploration since Greek times up to the medieval period (e.g., Photos-Jones et al., 2016). The generation of new minerals (hereinafter referred to as neogenesis) has received limited discussion in the recent literature (Cortecci et al., 1978; Valentino et al., 1999; Piochi et al., 2015; Russo et al., 2017). In contrast, several studies relate to bradyseism phenomena addressing the various aspects of seismicity, ground deformation and outgassing (e.g., Corrado et al., 1976; Barberi et al., 1984; Chiodini et al., 2016; Cardellini et al., 2017; Moretti et al., 2017), life in these environments (e.g., Zillig et al., 1996; Glamoclija et al., 2004; Sgavetti et al., 2008), and a continuous interest in the use of hydrothermal products as a thermal bath and for medical care (e.g., Photos-Jones et al., 2016; Giacomelli and Scandone, 2012).

This paper focuses on the solfataric mineral assemblages updating our previous research (Piochi et al., 2015) and presenting the result of our progressing work on the CF solfataric volcano. Results derive from temperature determinations contextually to sampling and investigations by optical microscope (OM), X-ray powder diffraction (XRDP), electron diffuse system-back-scattered electron microscopy (EDS-BSEM), diffuse Fourier infrared spectroscopy (DRIFT-FTIR), whole-rock geochemistry (WRG) and stable isotope geochemistry (SIG) of sulfur and oxygen. By merging new and published information (Celico, 1986; Guglielminetti, 1986; Rosi and Sbrana, 1987; Chiodini et al., 1988; Celico et al., 1992; Aiuppa et al., 2006; Caliro et al., 2007; Piochi et al., 2014; Di Giuseppe et al., 2017; Moretti et al., 2017), we reflect on the significance of the sulfate alteration zone and related volcanological implications.

\section{Background}

\subsection{Geological setting}

The Solfatara volcano (Fig. 1a, b, c) exhibits impressive and powerful hydrothermal activities with hot fumaroles, thermal springs, mud pools and diffuse outgassing (Allard et al., 1991; Valentino et al., 1999; Chiodini et al., 2001, 2010; Valentino and Stanzione, 2003, 2004; Piochi et al., 2015; Cardellini et al., 2017; and references therein). The hydrothermalism intensely altered the faulted volcano slopes (Rosi and Sbrana, 1987), and the solfataric landscapes (Fig. 1a-e) have locally replaced the original pyroclastic sequences (e.g., Agnano Monte Spina, Astroni and Solfatara tephra) and lavas (Monte Olibano, Solfatara cryptodome) younger than 5 ka (e.g., Di Vito et al., 1999; Piochi et al., 2005).

The study area is located at Puteoli, the area of maximum ground uplift (in excess of $3 \mathrm{~m}$ ) and seismicity (more than 16000 low-magnitude earthquakes), activated during the unrest episodes in 1970/1972 (Corrado et al., 1976) and in 1982/1984, namely "bradyseisms" (Barberi et al., 1984), that are slowly ongoing (e.g., Bodnar et al., 2007; Chiodini et al., 2016; Moretti et al., 2017).

The solfataric area has been exploited for centuries for its alum occurrences (Photos-Jones et al., 2016, and references therein). Intense mining during Roman and medieval times modified their original context (Photos-Jones et al., 2016): the Pisciarelli gorge valley was a quarry, while caving activity exposed the eastern (the Monte Olibano inner wall) and northern flanks of the Solfatara volcano and created rework deposits in the crater floor.

Old pictures and descriptions (Sicardi, 1959) suggest that the most evident manifestations along the SE and NE rims remain roughly the same: (1) the main Bocca Grande fumarole (Fig. 1d) with various exhalative branches northward along the morphological heights; (2) the minor fumarolic vents around the old thermal baths (Sst site; Fig. 1d); and (3) the mud pools (Fig. 1b, c, d, e). Also, the thermal spring in Pisciarelli (Fig. 1a, b, e), known as the "Bulla", i.e., the bubbling one, has been known at least since medieval times (PhotosJones et al., 2016). Moreover, the same descriptions indicate the presence of a lake in the Agnano Plain (Fig. 1a). According to Ventriglia (1942), the lake extended up to the slope base of the Solfatara volcano and had a maximum depth of $15 \mathrm{~m}$; drillings recovered related sediments (de Vita et al., 1999). Ventriglia (1942) also indicated high temperatures in the lake preventing fish from living. Today, the area shows several mud pools and thermal springs, while some ("de Pisis" and "Sprudel" springs in the Terme of Agnano; Fig. 1a) has disappeared. Yet, high temperatures can be still detected.

At present, groundwater nearby Solfatara are rich in $\mathrm{Cl}^{-}$ and $\mathrm{SO}_{4}^{-}$(Aiuppa et al., 2006). Temperatures at the fumaroles exceed $160^{\circ} \mathrm{C}$ (e.g., Cardellini et al., 2017; Gresse et al., 2017), in agreement (or lower with respect to local values) with measurements reported by Sicardi (1959) in the range of $141-215^{\circ} \mathrm{C}$ at Bocca Grande and of $99-110^{\circ} \mathrm{C}$ at other sites between 1921 and 1951. Pisciarelli waters exhibited temperatures mostly of around $95^{\circ} \mathrm{C}$ with minimum values of $84^{\circ} \mathrm{C}$ between 1978 and 1999 (Celico et al., 1992; Valentino and Stanzione, 2004). A geyser-like vent at Pisciarelli has a temperature of up to $116^{\circ} \mathrm{C}$ (Chiodini et al., 2016). Only, the mud pool (La Fangaia; Fig. 1d) was hotter in the past, with values up to $100^{\circ} \mathrm{C}$ (Sicardi, 1959). This latter author describes a mud vent in the southeastern area of the crater that is no longer present.

Emitted gases include $\mathrm{H}_{2} \mathrm{~S}, \mathrm{CH}_{4}, \mathrm{~N}_{2}, \mathrm{H}_{2}$ and $\mathrm{CO}$, in addition to the dominant water vapor and the secondary abundance of $\mathrm{CO}_{2}$ reaching a flux of at least $1500 \mathrm{td}^{-1}$ and a maximum value of $3000 \mathrm{td}^{-1}$ (Allard et al., 1991; Aiuppa 

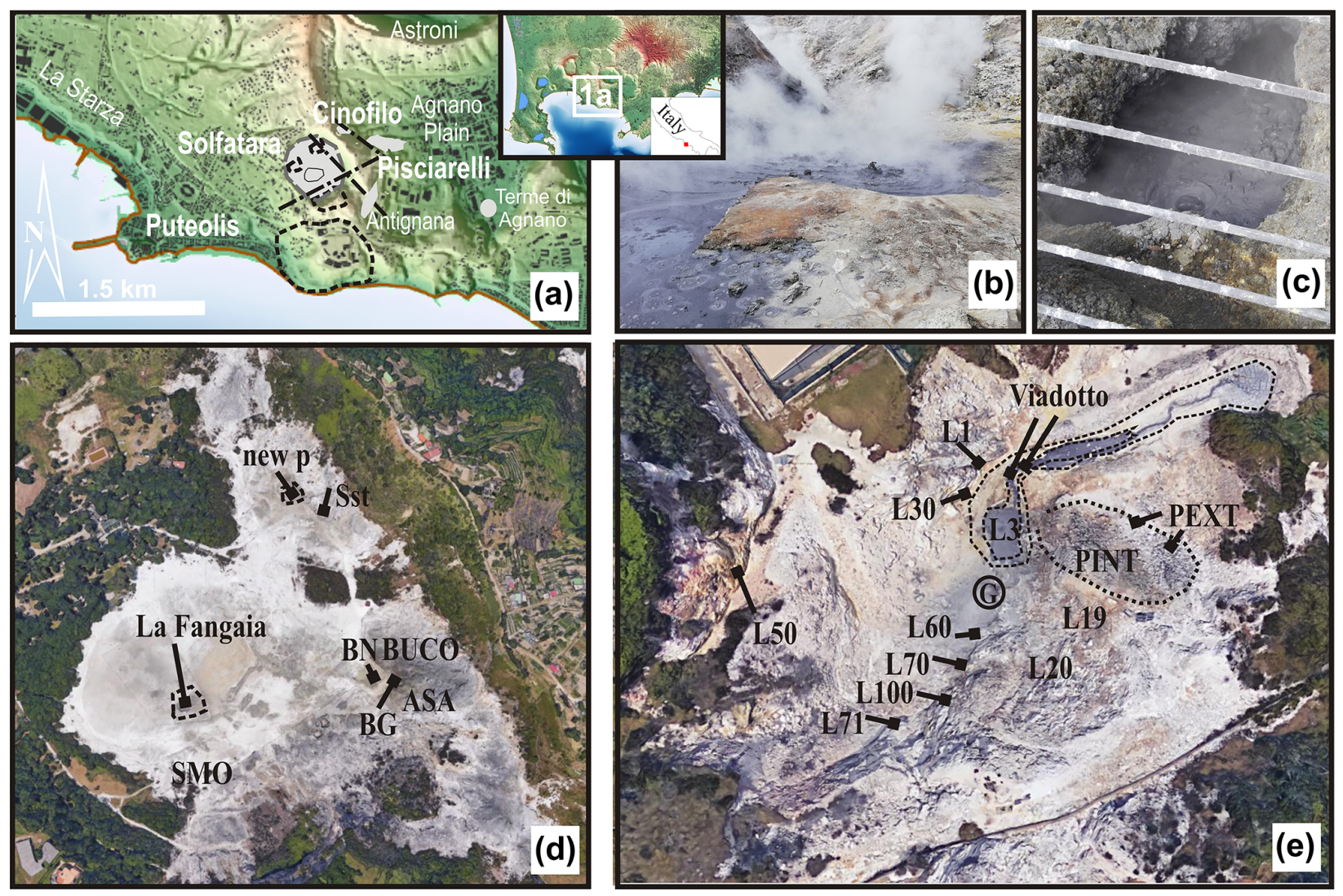

Figure 1. (a) The investigated acid sulfate areas (gray shaded) of Puteoli within the Campi Flegrei caldera (Italy): the Solfatara crater, Pisciarelli, Cinofilo, Antignana, Terme di Agnano. The map shows relevant structures: lava domes (dashed lines), fault systems (point-dash lines), La Starza marine terrace, the Astroni explosive crater and the Agnano Plain. (b) Pisciarelli pool on June 2018; (c) new pool (hereafter New P) at Solfatara on September 2017. (d) the Solfatara crater with sampling sites, notably the Bocca Grande fumarole (hereafter BG) and La Fangaia mud pool and the old thermal baths (hereafter Sst) as well. (e) The Pisciarelli sampling sites, notably geyser vent and mud pool (hereafter G and L3, respectively), the latter delineated by shaded lines defining the observed widening variations. Map in (a) modified by De Natale et al. (2016); Google Earth@ views in (d) and (e).

et al., 2013; Chiodini et al., 2016). Previous studies further report a $\mathrm{Hg}$ flux between 0.9 and $4.5 \mathrm{~g} \mathrm{~d}^{-1}$ (Ferrara et al., 1994; Bagnato et al., 2014), a detectable (yet very low) abundance of $\mathrm{SO}_{2}$ (Ferrara et al., 1994; Aiuppa et al., 2013), the occurrence of light hydrocarbons (Capaccioni and Mangani, 2001), and the presence of As and $\mathrm{Hg}(17-5200$ and 1-30 $\mu \mathrm{L}$, respectively; Valentino and Stanzione, 2003) in the pools and waters. High $\mathrm{NH}_{4}$ concentrations are described for waters at Pisciarelli (Martini et al., 1991; Celico et al., 1992; Valentino and Stanzione, 2003), but an understanding of the nitrogen source and cycling at the Phlegraean area, showing a unique isotopic composition with $\delta^{15} \mathrm{~N}$ at $6.3 \pm 0.3 \%$ (Chiodini et al., 2010), remains elusive. $\delta^{18} \mathrm{O}$ and $\delta^{2} \mathrm{H}$ of emitted fluids are in the range $-5 \%$ to $-0.5 \%$ and between $-30 \%$ and $-20 \%$, respectively (Caliro et al., 2007). The average $\delta^{34} \mathrm{~S}$ value of $\mathrm{H}_{2} \mathrm{~S}$ gases is $-0.3 \pm 0.3 \%$ (Allard et al., 1991). $\delta^{34} \mathrm{~S}$ values determined for shallow subsurface sulfur-bearing minerals range between $-5.5 \%$ and $0.0 \%$, while the deepseated pyrite shows values from $3.3 \%$ to $7.4 \%$ (Piochi et al., 2015). $\delta^{18} \mathrm{O}$ values for alunite vary from $4.2 \%$ to $7.0 \%$ o (Piochi et al., 2015). The $\mathrm{pH}$ of water pools and soils is neutral to acid, with $\mathrm{pH}$ values $<2$ around the pools (Valentino and Stanzione, 2003, 2004; Gresse et al., 2017).

\subsection{Sampling, sample preparation and analytical techniques}

Sampling was conducted within the Solfatara crater and in the Pisciarelli and Cinofilo areas (Fig. 1a, d, e) with additional sites compared to Piochi et al. (2015); the crater floor, except the pool, was intentionally avoided because of reworking in historical time (Photos-Jones et al., 2016) and thus possible anthropogenic contamination. This study enlarges the dataset on the acid sulfate alteration zone of the Phlegraean area, in order to understand the quiescent dynamics of the volcano. Similar observations and data are also available for Ischia island (Piochi et al., 2019), which belongs to the Phlegraean Volcanic District (Piochi et al., 2005). 

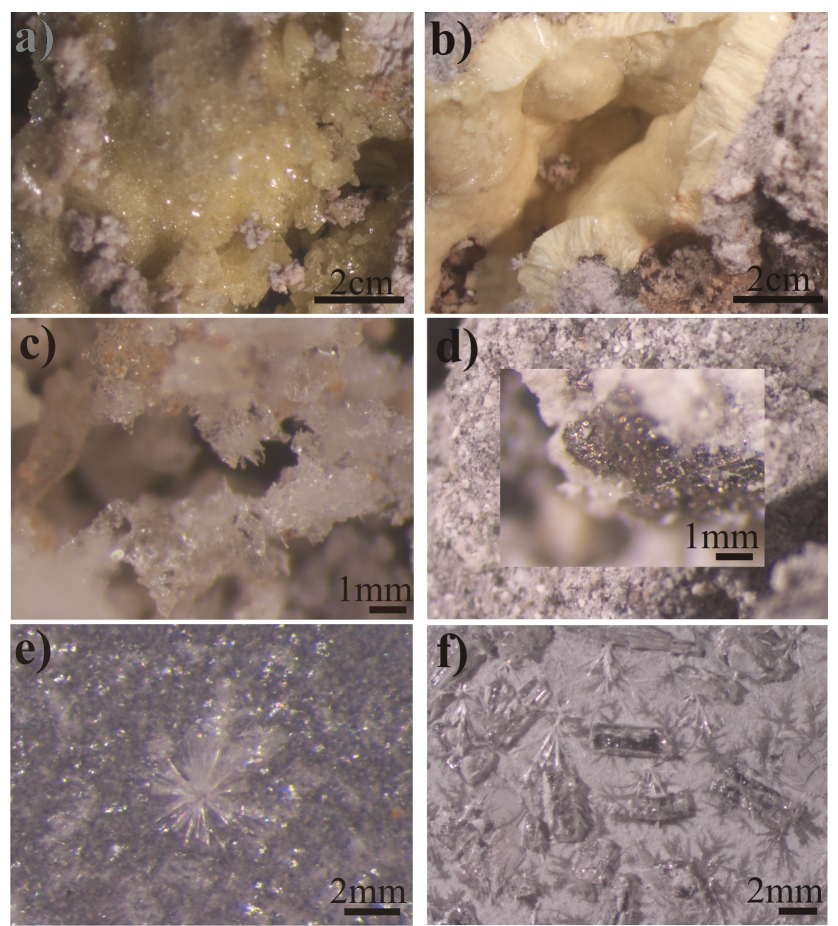

Figure 2. (a) Dendritic crystals of native sulfur growing on the alunite-dominant matrix; (b) native sulfur fibers that are typically detected in L60 and in several exhalative vents on PINT, PEXT and L20; (c) encrustations of alunite and alunogen at L1; (d) pyrite in the mud; (e) $\mathrm{NH}_{4}$ sulfates from evaporated L60 water; (f) $\mathrm{NH}_{4}$ sulfates from evaporated L3 water. All images were taken using a binocular microscope. Refer to Fig. 1a, d, e for listed sites.

Our new collection is, therefore, widening the observation period for the Puteoli sulfate area that now spans between January 2013 and April 2019 (Table S1 in the Supplement). Selection of sampling sites (hereinafter referred using the abbreviations in Fig. 1d, e) is based on variable macroscopic features including outgassing "magnitude", tectonics and fracturing evidence, mineral occurrences, and exhalative vent locations, as visible in the field and described in the literature (Allard et al., 1991; Ferrara et al., 1994; Valentino and Stanzione, 2003; Aiuppa et al., 2013; Bagnato et al., 2014; Chiodini et al., 2016). A thermocouple digital probe 51/52 II by Fluke with precision of $\pm 0.3^{\circ} \mathrm{C}$ was used to measure temperature in the field, contextually to sample collection.

Samples were air-dried for several days to 1 week. Subsequently, these were studied under the OM in order to assess their general mineral assemblages. Where possible, the various S-bearing phases (or enriched portions) were handpicked for subsequent isotopic analyses. Figures 2 and 3 show the appearance of the most representative samples.

Both bulk rocks and separated phases were pulverized in an agate mortar for XRDP, DRIFT-FTIR and WRG. EDSBSEM and SIG used aliquots of bulk materials and isolated mineral phases. Appendix A provides detailed information about analytical techniques. Details on XRDP and DRIFTFTIR are in the Supplement together with representative patterns (Figs. S1, S2).

\section{Results}

\subsection{Mineral data by OM, XRDP, EDS-BSEM and DRIFT-FTIR results}

New and previously published (Piochi et al., 2015) mineralogical data for the Solfatara-Pisciarelli area (Tables S1, 1) have provided information on a yearly to monthly basis since 2013 along with measurements of temperature. The mineral assemblage dataset derives from XRDP analyses (Supplement) corroborated by textural and chemical information obtained at the EDS-BSEM. DRIFT-FTIR spectra determined on representative samples display characteristic bands of minerals they include (see below and Supplement) and help in material characterization.

Through time, K, Al sulfates (alunite) and native S (Fig. 3) are the main and widely distributed secondary mineral phases associated with surface degassing. Alunogen and pyrite (Fig. 3a, b, d, e, h, i) are second in abundance. All these mineral phases can form single phase concretion or coexist in up to millimeter-sized grains. Alunogen often - if not generally - associates with alunite and occurs in two distinct morphologies (Fig. 3b, d, e). Most commonly, it consists of fibrous tangled masses of white crystals. Where they coexist, alunogen fibers grow from the edges of alunite crystals (e.g., sample L100 zucc in Table 1; Fig. 3d). This appearance seems usual along the fault scarp, north of the pool (L1 site, Fig. 1e). Subordinately, alunogen has thin, platy crystal habits (Fig. 3b, d, e). Many of these crystal groups show rounded to corroded edges suggesting alteration after crystallization (Fig. 3e). Dendritic and/or sometimes bipyramidal crystallites (Figs. 2a, 3) are ubiquitous habits for native sulfur (typically sampled at L1, SMO, some places along ASA, Sst in Fig. 1d, e and Table 1) that mostly cluster within the alunitic surface and the rock voids (Fig. 2c). Along the fracture, sulfur may form a yellow ductile patina (L1 vent, BG, BN in Fig. 1d, e and Table 1). Locally (PINT, PEXT, L19, L20, L60 in Fig. 1e and Table 1), sulfur produces encrustations with a pale yellowish fibrous-like texture (Fig. 2b).

Pyrite (Fig. 2d) occurs as smaller ( $\leq$ millimeter-sized) rhombododecahedric grains (Fig. 3a) or as fine-grained mineral uniformly coating other components (i.e., feldspars, lava, etc.; Figs. 2d, 3i). It has a particularly high abundance within the Pisciarelli muds (Figs. 1e, 2d), i.e., both within the main pool where it could reach centimeter sizes and in the geyser ( $\mathrm{G}$ site in Fig. 1e) emission. The blackish color of the muds should also derive from the pyrite abundance. Pyrite also occurs around the degassing areas. Barite can be further detected at Pisciarelli (Fig. 3a). 


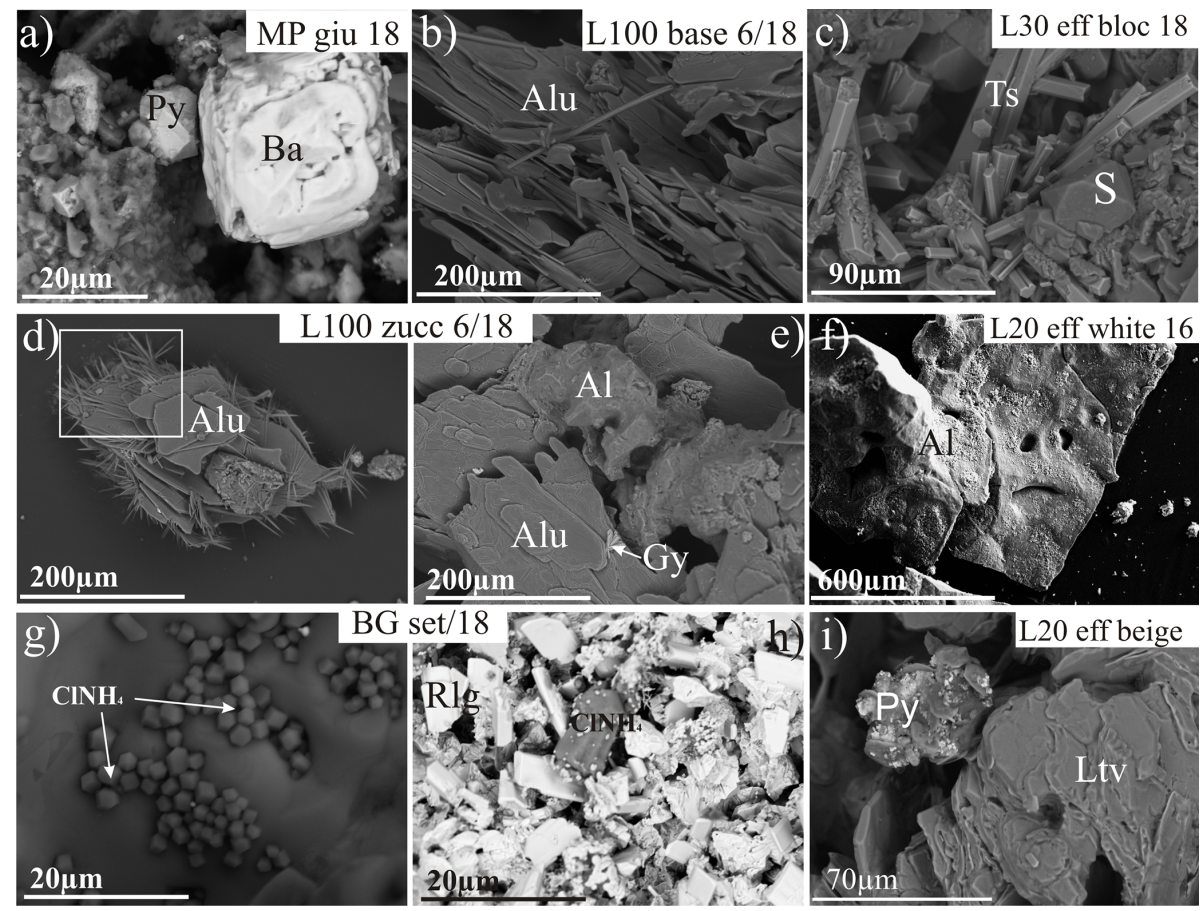

Figure 3. BSEM image showing sample texture and occurrences of S-bearing phases identified by EDS and XRDP analyses at the Puteoli sulfate lands: (a) orthorhombic barite (Ba) front of pentagonal pyrite (Py) from the Pisciarelli mud (L3); (b) irregular platy alunogen (Alu) oriented parallel to the fracture axis; (c) rhombic native sulfur (S) with bladed tschermigite crystals (Ts); (d) acicular alunogen (Alu) crystals developed above early tabular alunogen species; (e) euhedral alunite grains (Al) showing resorbed surfaces and coexisting with tabular alunogen (Alu) and acicular gypsum (Gy) crystals; (f) massive alunite (Al) encrustation; (g) pseudo-cubic ammonium chloride $\left(\mathrm{ClNH}_{4}\right)$ crystals within encrustation sampled at Bocca Grande (BG); (h) monoclinic realgar (Rlg) and ammonium chloride (ClNH) individuals at Bocca Grande (BG); (i) grains coated by pyrite and massive letovicite crystals. Alu - alunogen; $\mathrm{Al}$ - alunite; $\mathrm{Ba}_{-}$barite; $\mathrm{ClNH}_{4}-$ ammonium chloride (salammoniac); Gy - gypsum; Ltv - letovicite; py - pyrite; Rlg - realgar; S - native S; Ts - tschermigite. Sample names as in Table S1. Refer to Fig. 1e for site location.

Clays have a low relative abundance in the studied samples (Supplement). They are mostly kaolinite and illite (Tables S1, 1), as derived by the XRDP traces (see Fig. S1c, $\mathrm{d}, \mathrm{e})$ and supported by EDS-BSEM and DRIFT-FTIR study (see below; Fig. S2 and Supplement). In particular, the infrared technique is suitable to detecting the kaolinite and the related bands in the $\mathrm{OH}$ region, in agreement with Madejová et al. (2002). Illite usually occurs in the muds at Pisciarelli (from the geyser and around other emissive vents) and occasionally at Solfatara (Tables 1, S1). Kaolinite characterizes the newly formed pool within the Solfatara crater and occurs locally at Pisciarelli (Fig. 1c, d, e and Table 1). Figure 4 illustrates the platy particles of kaolinite with typical widths of $<10 \mu \mathrm{m}$ that assemble in packages and are associated with alunite crystals.

Other efflorescent phases (Fig. 3c, i) occur randomly. Rarely, $\mathrm{Al}$ and $\mathrm{Fe}$ sulfates (halotrichite) have been identified nearby the Pisciarelli geyser as crust-like aggregates. Na and $\mathrm{NH}_{4}$ sulfates induce the pale orange painting on efflorescences and encrustations and generally of soils. Sulfates, bearing $\mathrm{Na}, \mathrm{Ca}$ and $\mathrm{Mg}$ are least common and represent a typical occurrence in the new Solfatara mud. Alum has been detected at Pisciarelli.

Air-dried evaporation of water sampled at the Pisciarelli pool resulted in the precipitation of mascagnite, tschermigite and letovicite (Figs. 2e, f, S1a and Tables S1, 1). Figure 3c shows the euhedral tschermigite that coexists with native $S$ in the sample L30 eff-blocchetto (Tables S1, 1). Instead, evaporation of Solfatara mud pool water produced alum, as documented already in medieval and Roman times (Photo-Jones et al., 2016). Water from the Stufe di Nerone (west side not shown in figure) crystallized halite.

Realgar (sometimes only detected at the EDS-BSEM and not listed in Table S1) and ammonium chloride (Fig. $3 \mathrm{~g}$, h) appear as peculiar precipitates at the Bocca Grande and Bocca Nuova sites (Fig. 1d).

Accessory minerals include hematite, quartz and, possibly, Fe hydroxides and phlogopite.

Furthermore, amorphous phases are largely present at various sites (Tables S1, 1), particularly, in muds and in the samples from Bocca Grande and the L1 vent (Fig. 1d, e). The widespread amorphous phases could correspond to material from both the original volcanic rock and alteration. General 
Table 1. Main hydrothermal minerals detected by XRPD with related ideal chemical formula and sites of occurrence (names as in Fig. 1a, d, e). The complete set of minerals is in Table S1. Refer to the Supplement for details.

\begin{tabular}{|c|c|c|}
\hline Phase & Composition & Location \\
\hline Alunite & $\mathrm{KAl}_{3}\left(\mathrm{SO}_{4}\right)_{2}(\mathrm{OH})_{6}$ & Ubiquitous \\
\hline Alunogen & $\mathrm{Al}_{2}\left(\mathrm{SO}_{4}\right)_{3} \cdot 17\left(\mathrm{H}_{2} \mathrm{O}\right)$ & L1, SSt, L30, CIN, L100, L3, L70, L60, G \\
\hline Alum-(K) & $\mathrm{KAl}\left(\mathrm{SO}_{4}\right)_{2} \cdot 12\left(\mathrm{H}_{2} \mathrm{O}\right)$ & L1, L20, PP1 \\
\hline Alum-(Na) & $\operatorname{NaAl}\left(\mathrm{SO}_{4}\right)_{2} \cdot 12\left(\mathrm{H}_{2} \mathrm{O}\right)$ & L50, New P, L20 \\
\hline Amarillite & $\mathrm{NaFe}^{3+}\left(\mathrm{SO}_{4}\right)_{2} \cdot 6\left(\mathrm{H}_{2} \mathrm{O}\right)$ & L1 \\
\hline Biotite & $\mathrm{K}\left(\mathrm{Mg}, \mathrm{Fe}^{++}\right)_{3}\left[\mathrm{AlSi}_{3} \mathrm{O}_{10}(\mathrm{OH}, \mathrm{F})_{2}\right.$ & MS, L3 \\
\hline Chabazite & $\left(\mathrm{Ca}_{0.5}, \mathrm{Na}, \mathrm{K}\right)_{4}\left[\mathrm{Al}_{4} \mathrm{Si}_{8} \mathrm{O}_{24}\right] \cdot 12 \mathrm{H}_{2} \mathrm{O}$ & L50, L30 \\
\hline Clairite & $\left(\mathrm{NH}_{4}\right)_{2} \mathrm{Fe}_{3}^{3+}\left(\mathrm{SO}_{4}\right)_{4}(\mathrm{OH})_{3} \cdot 3\left(\mathrm{H}_{2} \mathrm{O}\right)$ & $\mathrm{G}$ \\
\hline Coquimbite & $\mathrm{Fe}_{2}^{+++}\left(\mathrm{SO}_{4}\right)_{3} \cdot 9\left(\mathrm{H}_{2} \mathrm{O}\right)$ & L50, L3, L1 \\
\hline Gypsum & $\mathrm{CaSO}_{4} \cdot 2\left(\mathrm{H}_{2} \mathrm{O}\right)$ & L50, L20, L3, L60, CIN, L100, SSt \\
\hline Halotrichite & $\mathrm{Fe}^{++} \mathrm{Al}_{2}\left(\mathrm{SO}_{4}\right)_{4} \cdot 22\left(\mathrm{H}_{2} \mathrm{O}\right)$ & $\mathrm{G}$ \\
\hline Hexahydrite & $\mathrm{Mg}\left(\mathrm{SO}_{4}\right) \cdot 6\left(\mathrm{H}_{2} \mathrm{O}\right)$ & CIN \\
\hline Hematite & $\mathrm{Fe}_{2} \mathrm{O}_{3}$ & PINT, L3 \\
\hline Kaolinite & $\mathrm{Al}_{2} \mathrm{Si}_{2} \mathrm{O}_{5}(\mathrm{OH})_{4}$ & New P, PINT, L19, L20 \\
\hline Koktaite & $\left(\mathrm{NH}_{4}\right)_{2} \mathrm{Ca}\left(\mathrm{SO}_{4}\right)_{2} \cdot\left(\mathrm{H}_{2} \mathrm{O}\right)$ & $\mathrm{L} 3, \mathrm{G}$ \\
\hline Illite & $\left(\mathrm{K}, \mathrm{H}_{3} \mathrm{O}\right)(\mathrm{Al}, \mathrm{Mg}, \mathrm{Fe})_{2}(\mathrm{Si}, \mathrm{Al})_{4} \mathrm{O}_{10}\left[(\mathrm{OH})_{2},\left(\mathrm{H}_{2} \mathrm{O}\right)\right]$ & $\begin{array}{l}\text { Widespread at Pisciarelli (L20, L3, L50, } \\
\text { G), CIN, rare at Solfatara }\end{array}$ \\
\hline Jarosite & $\mathrm{KFe}_{3}^{+++}\left(\mathrm{SO}_{4}\right)_{2}(\mathrm{OH})_{6}$ & L50, G, CIN, L30 \\
\hline Letovicite & $\left(\mathrm{NH}_{4}\right)_{3} \mathrm{H}\left(\mathrm{SO}_{4}\right)_{2}$ & L3, L1, L20 \\
\hline Marialite & $\mathrm{Na}_{4} \mathrm{Al}_{3} \mathrm{Si}_{9} \mathrm{O}_{24} \mathrm{Cl}$ & L3 \\
\hline Mascagnite & $\left(\mathrm{NH}_{4}\right)_{2} \mathrm{SO}_{4}$ & L1, G, L20, L3, L60, New P, BG \\
\hline Melanterite & $\mathrm{Fe}^{++} \mathrm{SO}_{4} \cdot 7\left(\mathrm{H}_{2} \mathrm{O}\right)$ & L3 \\
\hline Mereiterite & $\mathrm{K}_{2} \mathrm{Fe}^{2+}\left(\mathrm{SO}_{4}\right)_{2} \cdot 4\left(\mathrm{H}_{2} \mathrm{O}\right)$ & $\mathrm{L} 1$ \\
\hline Minamiite & $(\mathrm{Na}, \mathrm{Ca}, \mathrm{K}) \mathrm{Al}_{3}\left(\mathrm{SO}_{4}\right)_{2}(\mathrm{OH})_{6}$ & New $P$ \\
\hline Mohrite & $\left(\mathrm{NH}_{4}\right)_{2} \mathrm{Fe}_{2}^{+}\left(\mathrm{SO}_{4}\right)_{2} \cdot 6\left(\mathrm{H}_{2} \mathrm{O}\right)$ & L3 \\
\hline Montmorillonite & $(\mathrm{Na}, \mathrm{Ca})_{0,3}(\mathrm{Al}, \mathrm{Mg})_{2} \mathrm{Si}_{4} \mathrm{O}_{10}(\mathrm{OH})_{2} \cdot n\left(\mathrm{H}_{2} \mathrm{O}\right)$ & L50, L3, L20, CIN, SSt, G \\
\hline Natroalunite & $\mathrm{NaAl}_{3}\left(\mathrm{SO}_{4}\right)_{2}(\mathrm{OH})_{6}$ & L60 \\
\hline Periclase & $\mathrm{MgO}$ & $\mathrm{SSt}$ \\
\hline Pickeringite & $\mathrm{MgAl}_{2}\left(\mathrm{SO}_{4}\right)_{4} \cdot 22\left(\mathrm{H}_{2} \mathrm{O}\right)$ & L1 \\
\hline Picropharmacolite & $\mathrm{Ca}_{4} \mathrm{Mg}\left(\mathrm{AsO}_{3} \mathrm{OH}\right)_{2}\left(\mathrm{AsO}_{4}\right)_{2} \cdot 11\left(\mathrm{H}_{2} \mathrm{O}\right)$ & CIN \\
\hline Pyrite & $\mathrm{FeS}_{2}$ & $\begin{array}{l}\text { L3, BG, ASA, L1, G, New P, MS, L20, } \\
\text { viadotto }\end{array}$ \\
\hline Realgar & $\mathrm{As}_{4} \mathrm{~S}_{4}$ & $\mathrm{BG}, \mathrm{BN}$ \\
\hline Rostite & $\mathrm{AlSO}_{4}(\mathrm{OH}, \mathrm{F}) \cdot 5\left(\mathrm{H}_{2} \mathrm{O}\right)$ & SSt \\
\hline Salammoniac & $\left(\mathrm{NH}_{4}\right) \mathrm{Cl}$ & $\mathrm{BG}, \mathrm{BN}$ \\
\hline Sulfur & $\mathrm{S}^{0}, \mathrm{~S}_{8}$, beta & Ubiquitous, subordinated in L3 \\
\hline $\begin{array}{l}\text { Silica essentially as opal } \\
\text { and quartz }\end{array}$ & $\mathrm{SiO}_{2}$ & SSt, L1, BG, CIN, L20, L50 \\
\hline Tamarugite & $\mathrm{NaAl}\left(\mathrm{SO}_{4}\right)_{2} \cdot 6\left(\mathrm{H}_{2} \mathrm{O}\right)$ & L20, CIN \\
\hline Tschermigite & $\left(\mathrm{NH}_{4}\right) \mathrm{Al}\left(\mathrm{SO}_{4}\right)_{2} \cdot 12\left(\mathrm{H}_{2} \mathrm{O}\right)$ & L20, L3, L60, L70, G \\
\hline Vermiculite & $\left(\mathrm{Mg}, \mathrm{Fe}^{++}, \mathrm{Al}\right)_{3}(\mathrm{Al}, \mathrm{Si})_{4} \mathrm{O}_{10}(\mathrm{OH})_{2} \bullet 4\left(\mathrm{H}_{2} \mathrm{O}\right)$ & L3 \\
\hline Voltaite & $\mathrm{K}_{2} \mathrm{Fe}_{5}^{2+} \mathrm{Fe}_{3}^{3+} \mathrm{Al}\left(\mathrm{SO}_{4}\right)_{12} \cdot 18\left(\mathrm{H}_{2} \mathrm{O}\right)$ & L1vent, L100, G \\
\hline Zaherite & $\mathrm{Al}_{12}\left(\mathrm{SO}_{4}\right)_{5}(\mathrm{OH})_{26} \cdot 20\left(\mathrm{H}_{2} \mathrm{O}\right)$ & G, CIN, L100 \\
\hline
\end{tabular}

assumptions (Piochi et al., 2015; Montanaro et al., 2017) indicate amorphous silica, although this merits a more rigorous examination.

Finally, Fe oxide and fresh to variably altered feldspar and biotite are the most common primary volcanic mineral phases.

DRIFT-FTIR spectra collected on selected samples (Fig. S2) produce data consistent with XRDP results
(Fig. S1) and furthermore allow useful details on structure and eventual minor phases or impurities (Supplement). Table S2 lists the relevant vibration modes of spectra and the proposed mineral assignments. The crystals formed by evaporation of water in the Pisciarelli pool (Fig. S2a; Supplement) show a sharp band at $1422-1411 \mathrm{~cm}^{-1}$ that is in the region of the $v_{4}\left(\mathrm{NH}_{4}^{+}\right)$, as described in the literature (e.g., Weis and 

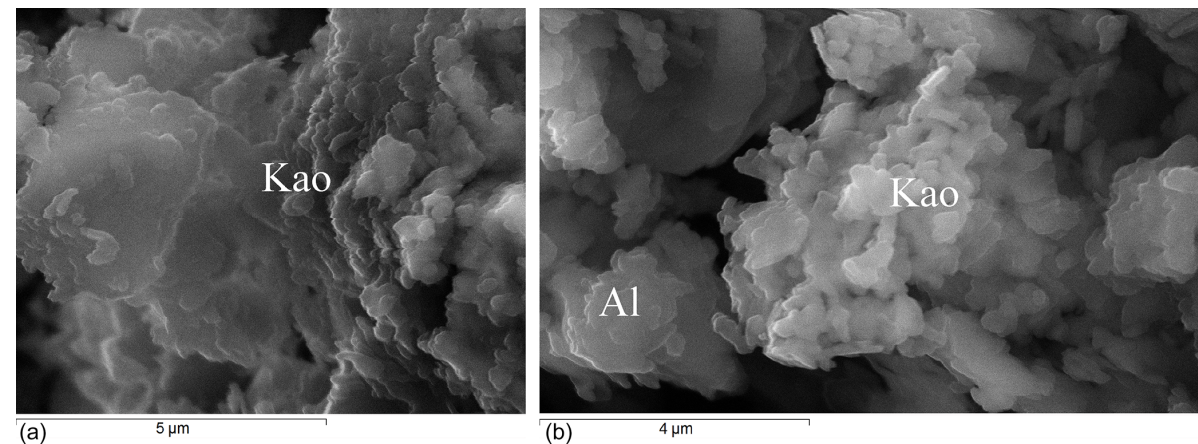

Figure 4. BSEM image of kaolinite platy crystals at the new pool of Solfatara (New P, Fig. 1c, d): the kaolinite plates have a tendency to assembly (a) and associate with alunite (b). Kao - kaolinite; $\mathrm{Al}$ - alunite.

Ewing, 1996; Parafiniuk and Kruszewky, 2010) and in agreement with XRDP mineral data (Table S1; Fig. S1).

Native $\mathrm{S}$ from two different samples (PINT $\mathrm{S}$ tozzo 18/10/17 and PINT S 18/1/18 in Table 1; Fig. S2b) is evident in the DRIFT-FTIR spectra at $<2950 \mathrm{~cm}^{-1}$, with the strongest bands at 843 and $468 \mathrm{~cm}^{-1}$ that coincide with those of sulfur in both the USGS (see Sulfur GDS94; Clark et al., 2007) and RRUFF (http://rruff.info/, last access: 23 March 2018) databases. The spectra differ in the $\mathrm{OH}-$ stretching region, likely indicating the occurrence of impurities, although water absorption by the $\mathrm{KBr}$ solution can be a further possibility.

As expected (Clark et al., 1990), alunite can be determined through its major band at $3483 \mathrm{~cm}^{-1}$ coupled with a smaller one at $3513 \mathrm{~cm}^{-1}$ in the $\mathrm{OH}$-stretching region (Fig. S2c, d, e). Accordingly, the spectra show a small band at ca. $4605 \mathrm{~cm}^{-1}$ from the Al-OH combination mode that should be ascribed to alunite. Furthermore, it is possible to recognize the doublet mode at $1088 / 1099 \mathrm{~cm}^{-1}$ and at $1028 / 1025 \mathrm{~cm}^{-1}$ (Toumi and Tlili, 2008) and the mode at $3971 / 3978 \mathrm{~cm}^{-1}$ (see USGS database; Clark et al., 2007) from alunite. However, in the $\mathrm{OH}$-stretching region there are some other vibrations. Based on Madejovà and Komadel (2001), illite is likely producing the vibration at $3622 / 3629 \mathrm{~cm}^{-1}$.

Notably, the DRIFT-FTIR spectra of muds from Pisciarelli (Fig. S2d) show a vibration in the region of $1430 \mathrm{~cm}^{-1}$. Because the muds were separated from water, as before, the band can be related to the $\mathrm{NH}_{4}$ (Weis and Ewing, 1996; Parafiniuk and Kruszewky, 2010) in tschermigite, mascagnite and letovicite (Table S1, Figs. S2 and S1, Supplement).

The new pool at Solfatara has peculiar DRIFT-FTIR spectra in the $\mathrm{OH}$-stretching region (Fig. S2e; note the inset) due to the presence of kaolinite, in addition to alunite, and minor (or occasional) sulfur, feldspar, pyrite and amorphous phases. Specifically, these are (i) alunite (Clark et al., 1990) with a major band at $3483 \mathrm{~cm}^{-1}$ coupled with a smaller one at $3510 \mathrm{~cm}^{-1}$ and (ii) kaolinite (Madejová, 2003) with two minor bands at 3667 and $3651 \mathrm{~cm}^{-1}$ between two major vibrational modes at 3695 and $3620 \mathrm{~cm}^{-1}$. Accordingly, it is possible to recognize the $\mathrm{OH}$ deformation at ca. 915 and $938 \mathrm{~cm}^{-1}$, the Si-O stretch at 1008 and $1026 \mathrm{~cm}^{-1}$, and the Al-OH modes at ca. 4605 and $4523 \mathrm{~cm}^{-1}$ from kaolinite.

The four vibration modes of kaolinite in Fig. S2e point to a well-ordered mineral structure (Madejová, 2003; Fitos et al., 2015), giving strong support to the XRDP results (Fig. S1e, Supplement), also in multiphase samples (Madejová et al., 2002).

\subsection{Stable isotopes of sulfur and oxygen (SGI)}

A new set of $\delta^{34} \mathrm{~S}$ and $\delta^{18} \mathrm{O}$ values for sulfur-bearing minerals is listed in Table 2. $\delta^{34} \mathrm{~S}$ values of sulfides and native $\mathrm{S}$ range between $-3.00 \%$ and $0.49 \%$ and between $-4.42 \% o$ and $0.80 \%$, respectively. Sulfates are characterized by $\delta^{34} \mathrm{~S}$ and $\delta^{18} \mathrm{O}$ values ranging from $-2.78 \%$ to $2.09 \%$ and from $4.60 \%$ to $31.33 \%$, respectively. Temporal variations in $\delta^{34} \mathrm{~S}$ for different sulfur-bearing phases at the different locations reveal a dominantly negative signature, regardless of their mineralogy, with native $\mathrm{S}$ showing the most negative values (Fig. 5).

The new sulfur isotope results are generally comparable with literature values for Campi Flegrei (Piochi et al., 2015), although studies earlier than 2000 (Cortecci et al., 1978; Valentino et al., 1999) also show positive $\delta^{34} S$ values (Fig. 5a, b). In comparison to previous studies

1. our new S-isotope data for Pisciarelli include a few positive values (Fig. 5b, c).

2. the new O-isotope values for sulfate are the highest obtained until now (Fig. 5d). To note, the muds generally have the least heavy oxygen isotopes, except for samples from 2013-2014 for which O-isotope determinations are lacking. The diagram also indicates a lowering in $\delta^{34} \mathrm{~S}$ for neoformed minerals reported later than 2000 .

3. the sulfides at Pisciarelli show $\delta^{34} \mathrm{~S}$ values mostly at $0 \%$ (Figs. 5, 6).

4. the different sites display a homogenous range in $\delta^{34} \mathrm{~S}$ (Fig. 5a, b, c); however, the variability for the ASA and 
Table 2. $\delta^{34} \mathrm{~S}$ vs. $\delta^{18} \mathrm{O}$ values of sulfur-bearing minerals. Sample name as in Tables 1 and $\mathrm{S} 1$; the muds are in italic.

\begin{tabular}{|c|c|c|c|c|c|c|c|c|c|}
\hline Type & Sample & $\begin{array}{r}\delta^{34} S \\
(\% \circ)\end{array}$ & SD & $\begin{array}{r}\delta^{18} \mathrm{O} \\
(\% \circ)\end{array}$ & SD & $\begin{array}{l}\text { Date } \\
\text { dd.mm.yy }\end{array}$ & Location $^{\mathrm{a}}$ & $\begin{array}{r}T \\
\left({ }^{\circ} \mathrm{C}\right)\end{array}$ & $\begin{array}{l}\text { Height } \\
(\mathrm{m})^{\mathrm{b}}\end{array}$ \\
\hline \multicolumn{10}{|c|}{ Pisciarelli } \\
\hline \multirow[t]{22}{*}{ Sulfate } & L1d1 al/11-15 & -1.78 & 0.06 & 11.93 & 0.23 & 01.11 .15 & $\mathrm{~L} 1$ & - & 67 \\
\hline & L1d2 white/11-15 & -2.08 & 0.05 & 15.05 & 0.44 & 01.11 .15 & L1 & - & 67 \\
\hline & $M P / 11-15$ & -1.93 & 0.01 & 10.33 & 0.00 & 01.11 .15 & $L 3$ & - & 66 \\
\hline & P PP1/11-15 & -0.30 & 0.21 & 17.25 & 0.08 & 01.11 .15 & $\mathrm{G}$ & 92 & 68 \\
\hline & $\mathrm{P} \mathrm{PPb} / 11-15$ & -1.27 & 0.13 & 17.85 & 0.41 & 01.11 .15 & $\mathrm{G}$ & 50.2 & 69 \\
\hline & P L50 yellow & -0.22 & 0.15 & 20.88 & 0.16 & 01.11 .15 & L50 & - & 84 \\
\hline & P L50 white & -0.40 & 0.02 & 21.54 & 0.27 & 01.11 .15 & L50 & - & 84 \\
\hline & P L50 red & -1.31 & 0.02 & 8.59 & 0.40 & 01.11 .15 & L50 & - & 84 \\
\hline & L1v PGw/6-16 & -2.78 & 0.07 & 13.09 & 0.43 & 01.06 .16 & L50 & - & 66.5 \\
\hline & L1 Pwh/6-16 & -2.13 & 0.00 & 5.72 & 0.30 & 01.06 .16 & L1 & 56.9 & 67 \\
\hline & L1 Psalt/6-16 & -2.12 & 0.13 & 5.95 & 0.19 & 01.06 .16 & L1 & 67 & 67 \\
\hline & L1 Pblack/6-16 & -0.41 & 0.04 & 9.52 & 0.21 & 01.06 .16 & $\mathrm{~L} 1$ & - & 67 \\
\hline & $M P / 6-16$ & -0.87 & 0.01 & 4.60 & 0.05 & 01.06 .16 & $L 3$ & 70 & 66 \\
\hline & GnvW bl/6-16 & 0.44 & 0.01 & 6.96 & 0.51 & 01.06 .16 & L19 & 74.7 & 68 \\
\hline & Gnv W be/6-16 & -0.31 & 0.23 & 12.44 & 0.22 & 01.06 .16 & L19 & 74.7 & 69 \\
\hline & PL20 v1/6-16 & -0.59 & 0.06 & 14.04 & 0.15 & 01.06 .16 & L20 & 90 & 71 \\
\hline & Ps 7-16 & -1.00 & 0.08 & 8.37 & 0.06 & 01.07 .16 & $L 3$ & - & 66 \\
\hline & PL 20V1 7-16 & -0.53 & 0.02 & 14.26 & 0.03 & 01.07 .16 & L20 & - & 71 \\
\hline & MP 29.6.17 & -0.09 & 0.03 & 6.82 & 0.2 & 29.06 .17 & $L 3$ & - & 66 \\
\hline & L1 beije 18.9 .17 & -0.89 & 0.02 & 22.14 & 0.51 & 18.09 .17 & $\mathrm{~L} 1$ & - & 67 \\
\hline & MP L3 boccetta 1.9.17 & -0.54 & 0.02 & 9.87 & 0.5 & 01.09 .17 & $L 3$ & 49.5 & 66 \\
\hline & $M P 18.1 .18$ & 0.26 & 0.06 & 13.21 & 0.2 & 18.01 .18 & $L 3$ & 77.1 & 66 \\
\hline \multirow[t]{9}{*}{ Sulfide } & $M P / 11-15$ & -0.08 & 0.05 & & & 01.11 .15 & $L 3$ & - & 66 \\
\hline & P PP1/11-15 & -0.69 & 0.07 & & & 01.11 .15 & $\mathrm{G}$ & 92 & 68 \\
\hline & L1 Pblack/6-16 & -3.00 & 0.07 & & & 01.06 .16 & $\mathrm{~L} 1$ & - & 67 \\
\hline & $M P / 6-16$ & -0.43 & 0.13 & & & 01.06 .16 & $L 3$ & 70 & 66 \\
\hline & GnvW bl/6-16 & -0.48 & 0.10 & & & 01.06 .16 & L19 & 74.7 & 68 \\
\hline & Ps 7-16 & -0.34 & 0.01 & & & 01.07 .16 & $L 3$ & - & 66 \\
\hline & MP 29.6.17 & 0.02 & 0.02 & & & 29.06 .17 & $L 3$ & - & 66 \\
\hline & MP L3 boccetta 1.9.17 & -0.49 & 0.02 & & & 01.09 .17 & $L 3$ & 49.5 & 66 \\
\hline & $M P 18.1 .18$ & -0.67 & 0.04 & & & 18.01 .18 & $L 3$ & 77.1 & 66 \\
\hline \multirow[t]{10}{*}{ Sulfur } & L1 Pv/6-16 & 0.80 & 0.14 & & & 01.06 .16 & L1 & 56.9 & 66.5 \\
\hline & Geyser mud & -2.26 & 0.04 & & & 01.06 .16 & $\mathrm{G}$ & - & 68 \\
\hline & PINT S 18.9.17 & -1.71 & 0.06 & & & 18.09 .17 & PINT & - & 74 \\
\hline & L1 S 18.9.17 & -0.06 & 0.00 & & & 18.09 .17 & $\mathrm{~L} 1$ & - & 67 \\
\hline & L 20 camino 18.9 .17 & -2.50 & 0.02 & & & 18.09 .17 & L20 & - & 76 \\
\hline & L1 vent S 14.12.17 & -2.67 & 0.01 & & & 14.12.17 & L1 & 94.7 & 67 \\
\hline & PINT S 18.1.18 & -0.91 & 0.12 & & & 18.01 .18 & PINT & 93.4 & 74 \\
\hline & L1 vent S 18.1.18 & -2.68 & 0.00 & & & 18.01.18 & $\mathrm{L} 1$ & 94 & 67 \\
\hline & $\mathrm{L} 1$ vent parete $\mathrm{S} 18.1 .18$ & -0.99 & 0.05 & & & 18.01.18 & L1 & 89.9 & 67.5 \\
\hline & L19 geyser S 18.1.18 & -2.30 & 0.01 & & & 18.01 .18 & L19 & 95.8 & 70 \\
\hline \multicolumn{10}{|c|}{ Solfatara } \\
\hline \multirow[t]{13}{*}{ Sulfate } & SStb/11-15 & -0.74 & 0.02 & 23.93 & 0.68 & 01.11 .15 & SSt & - & 100 \\
\hline & SSt wr/11-15 & 1.61 & 0.11 & 31.33 & 0.47 & 01.11 .15 & SSt & - & 100 \\
\hline & SStgc/11-15 & 0.91 & nd & & & 01.11 .15 & SSt & - & 100 \\
\hline & SMO S/6-16 & 2.09 & nd & & & 01.06 .16 & SMO & 87 & 109 \\
\hline & SMO ASA/6-16 & -2.09 & 0.10 & 8.18 & 0.11 & 01.06 .16 & SMO & - & 109 \\
\hline & ASA m/16-6 & -0.63 & 0.09 & 8.75 & 0.12 & 01.06 .16 & ASA & - & 124 \\
\hline & ASA h/16-6 & -0.67 & 0.05 & 6.62 & 0.25 & 01.06 .16 & ASA & - & 124 \\
\hline & SSt sub/16-6 & -1.52 & 0.11 & 9.59 & 0.30 & 01.06 .16 & SSt & 92 & 101 \\
\hline & $P S / 6-16$ & 0.31 & 0.23 & 7.43 & 0.24 & 01.06 .16 & La Fangaia & 52.9 & 94 \\
\hline & MS 29.6.17 & 0.80 & 0.00 & 18.58 & 0.3 & 29.06 .17 & La Fangaia & - & 94 \\
\hline & MS new 29.06.17 & -0.65 & 0.13 & 9.31 & 0.4 & 29.06 .17 & new pool & - & 94 \\
\hline & MS new 1.9.17 & -0.22 & 0.07 & 10.56 & 0.7 & 01.09 .17 & new pool & 70 & 94 \\
\hline & MS2 1.9.17 & 0.62 & 0.09 & 7.84 & 0.1 & 01.09 .17 & La Fangaia & 49.5 & 94 \\
\hline
\end{tabular}


Table 2. Continued.

\begin{tabular}{|c|c|c|c|c|c|c|c|c|c|}
\hline Type & Sample & $\begin{array}{l}\delta^{34} S \\
(\% o)\end{array}$ & SD & $\begin{array}{r}\delta^{18} \mathrm{O} \\
(\% o)\end{array}$ & SD & $\begin{array}{l}\text { Date } \\
\text { dd.mm.yy }\end{array}$ & Location $^{\mathrm{a}}$ & $\begin{array}{r}T \\
\left({ }^{\circ} \mathrm{C}\right)\end{array}$ & $\begin{array}{l}\text { Height } \\
(\mathrm{m})^{\mathrm{b}}\end{array}$ \\
\hline \multirow[t]{10}{*}{ Sulfide } & SSt wr/11-15 & -0.38 & 0.08 & & & 01.11 .15 & $\mathrm{SSt}$ & - & 100 \\
\hline & SMO ASA/6-16 & -2.92 & 0.08 & & & 01.06 .16 & SMO & - & 109 \\
\hline & ASA m/16-6 & -2.65 & 0.08 & & & 01.06 .16 & ASA & - & 124 \\
\hline & ASA h/16-6 & -1.96 & 0.09 & & & 01.06 .16 & ASA & - & 124 \\
\hline & $P S / 6-16$ & -0.11 & 0.07 & & & 01.06 .16 & La Fangaia & - & 94 \\
\hline & MS 29.6.17 & 0.24 & 0.11 & & & 29.06 .17 & La Fangaia & - & 94 \\
\hline & MS new 29.06.17 & -1.63 & 0.02 & & & 29.06 .17 & new pool & - & 94 \\
\hline & MS new 1.9.17 & -1.16 & 0.10 & & & 01.09 .17 & new pool & 70 & 94 \\
\hline & MS1 1.9.17 & 0.38 & 0.00 & & & 01.09 .17 & La Fangaia & 49.5 & 94 \\
\hline & MS2 1.9.17 & 0.49 & 0.00 & & & 01.09 .17 & La Fangaia & 49.5 & 94 \\
\hline \multirow[t]{19}{*}{ Sulfur } & BG pg/11-15 & -3.95 & 0.03 & & & 01.11 .15 & $\mathrm{BG}$ & 93.1 & 103 \\
\hline & SStgf/11-15 & -2.23 & 0.21 & & & 01.11 .15 & SSt & - & 100 \\
\hline & & -2.13 & 0.28 & & & 01.11 .15 & SSt & - & 100 \\
\hline & & -2.40 & 0.20 & & & 01.11 .15 & SSt & - & 100 \\
\hline & SStgc/11-15 & -3.34 & 0.38 & & & 01.11 .15 & SSt & - & 100 \\
\hline & & -1.52 & 0.00 & & & 01.11 .15 & SSt & - & 100 \\
\hline & & -2.43 & 0.09 & & & 01.11 .15 & SSt & - & 100 \\
\hline & BG S/6-16 & -4.42 & 0.29 & & & 01.06 .16 & BG & 93.2 & 103 \\
\hline & & -3.89 & 0.28 & & & 01.06 .16 & BG & 93.2 & 103 \\
\hline & & -4.21 & 0.21 & & & 01.06 .16 & BG & 93.2 & 103 \\
\hline & up BG S/6-16 & -3.84 & 0.06 & & & 01.06 .16 & BUCO & 93.2 & 106 \\
\hline & & -2.78 & 0.11 & & & 01.06 .16 & BUCO & 93.2 & 106 \\
\hline & & -3.46 & 0.15 & & & 01.06 .16 & BUCO & 93.2 & 106 \\
\hline & SMO S/6-16 & 0.29 & 0.28 & & & 01.06 .16 & SMO & 87 & 109 \\
\hline & & 0.44 & 0.24 & & & 01.06 .16 & SMO & 87 & 109 \\
\hline & & 0.22 & 0.04 & & & 01.06 .16 & SMO & 87 & 109 \\
\hline & SSt Sf/16-6 & -2.08 & 0.17 & & & 01.06 .16 & SSt & - & 124 \\
\hline & & -2.31 & 0.06 & & & 01.06 .16 & SSt & - & 124 \\
\hline & & -2.42 & 0.01 & & & 01.06 .16 & SSt & - & 124 \\
\hline
\end{tabular}

${ }^{\mathrm{a}}$ In Fig. 1. ${ }^{\mathrm{b}}$ From Google Earth®. Nd: not determined.

L1 sites reflects different sample heights along the slope (Fig. 1d) and wall (Fig. 1e), respectively.

5. a likely appearance of a positive correlation between Sisotope results for pyrite and for sulfate phases coexisting at Solfatara, with two from the 1994 data outside the trend (Fig. 6a).

6. new isotope data for sulfate reveal a difference compared to studies older than 1990 and the most recent one (Fig. 7).

In addition, the $\delta^{18} \mathrm{O}$ values for sulfates at Pisciarelli show a slight tendency to increase with topographic elevation at the sampling site. Specifically, the highest values generally occur at Solfatara, which is at $>96 \mathrm{~m}$ a.s.l., while Pisciarelli lies at 66-74 m a.s.1.

\subsection{Content of major and trace elements (WRG)}

Table S3 reports the whole-rock geochemical compositions of selected samples. As expected, samples are highly hydrated and sulfur-rich, due to the $\mathrm{OH}$ group and/or $\mathrm{S}$ in the crystalline network (see ideal formula in Table 1) and/or the presence of native $\mathrm{S}$ in the analyzed sample. LOI (loss on ignition) can be up to $80 \mathrm{wt} \%$ (sample L20 camino 18.9.17), although it is most commonly at $20 \mathrm{wt} \%-30 \mathrm{wt} \%$, and the $\mathrm{S}$ content is up to more than $50 \mathrm{wt} \%$. Carbon is generally low $(<1.25 \mathrm{wt} \%)$, and always $<22 \mathrm{wt} \%$. Notably, the $\mathrm{SiO}_{2}$ content is highly variable. Depending on the sample mineralogy, it can be as high as $70 \mathrm{wt} \%-80 \mathrm{wt} \%$. MnO is always $<0.1 \mathrm{wt} \%$.

With respect to the local volcanic rock substrate (Table S3; Fig. 8a), some lithophile elements ( $\mathrm{Si}, \mathrm{Al}, \mathrm{P}, \mathrm{Sc}, \mathrm{Ti}, \mathrm{V}, \mathrm{Zr}, \mathrm{Ba}$, $\mathrm{Yb}, \mathrm{Th}, \mathrm{Hf}$ ) are comparable or depleted (for examples, Be at $<1-5$ ppm vs. $>4$ ppm, Rb $<95.6$ ppm, $\mathrm{Y}<8.1 \mathrm{ppm}$ ). Depletion concerns $\mathrm{Na}, \mathrm{Mg}, \mathrm{K}, \mathrm{Ca}, \mathrm{Rb}, \mathrm{Eu}$ and $\mathrm{U}$ content. Only $\mathrm{Ba}$ displays a significant level of enrichment reaching very high values up to thousands of parts per million. Cs shows concentrations of up to tens of parts per million. Siderophile and chalcophile ratios (Fig. 8b) mostly lie at 1 or slightly above, with depletions for $\mathrm{Fe}, \mathrm{Zn}$ and $\mathrm{Ga}(\mathrm{Ga}<23.8 \mathrm{ppm})$ and enrichments for $\mathrm{S}, \mathrm{Au}, \mathrm{As}, \mathrm{Tl}$ and $\mathrm{Hg}$ (Table S3). Sb can be higher than the primary rock composition. 


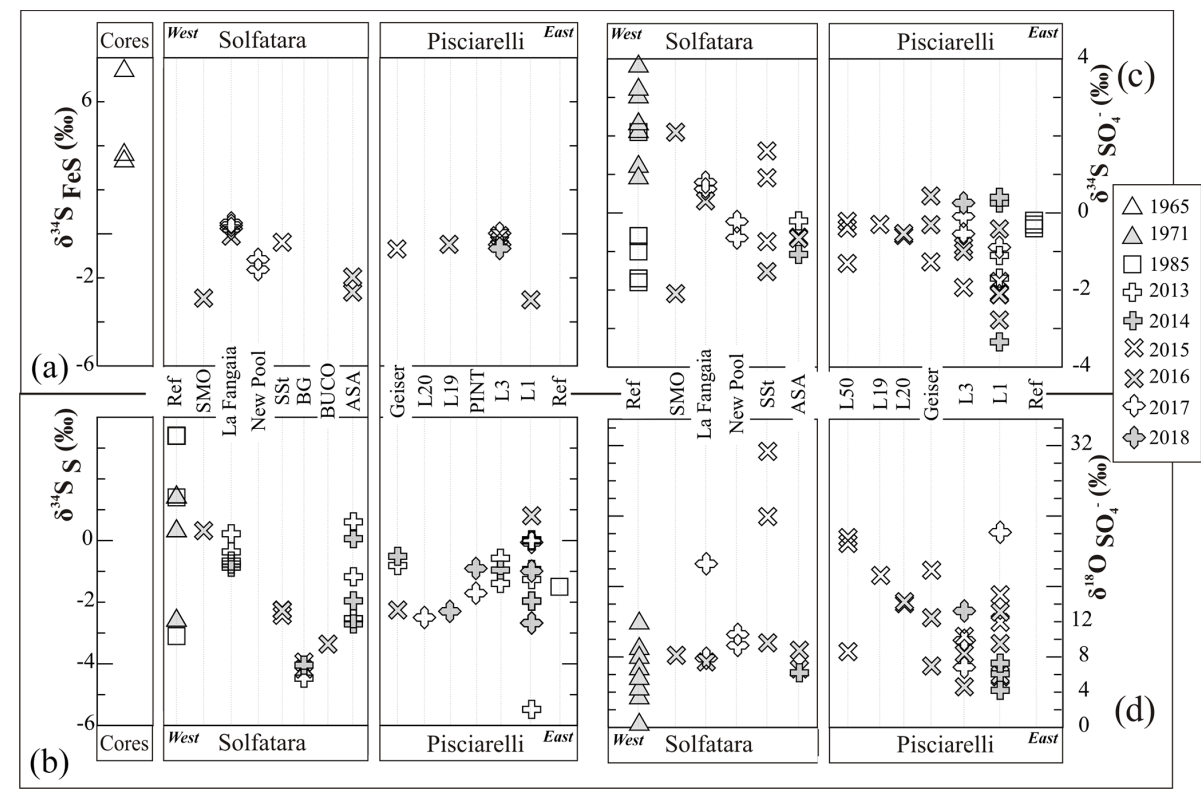

Figure 5. Distribution of $\delta^{34} \mathrm{~S}$ values for sulfides (a), native sulfur (b) and sulfates (c) and of $\delta^{18} \mathrm{O}$ values for sulfates at the different sampling sites arranged by sampling date. Results from cores collected in 1965 and 1971, 1984, 2013 and 2014 are compiled from the literature (i.e., Cortecci et al., 1978; Valentino et al., 1999; Valentino and Stanzione, 2003, 2004; Piochi et al., 2015). Sampling sites are shown in Fig. 1a, d, e; "Ref" indicates literature data. Note the values are plotted based on sample sites, from west to east.
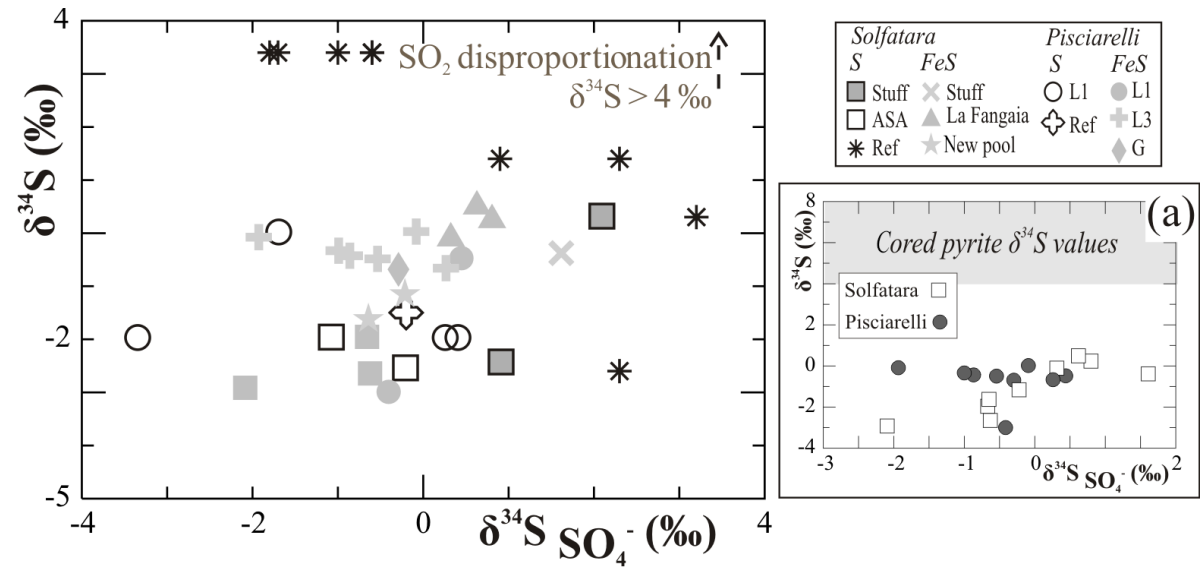

Figure 6. Distribution of $\delta^{34} \mathrm{~S}$ values among coexisting sulfates, sulfides and native sulfur ( $\mathrm{S}$ in legend), organized on the basis of the sampling sites. Note: (i) the nearly similar values of sulfates and sulfides at Solfatara coherent with supergene setting; (ii) the higher $\delta^{34} \mathrm{~S}$ values in sulfides at Pisciarelli indicating a different, likely not biogenic (in that case sulfate must be heavy) process or stage; (iii) likely positive correlations between Solfatara sulfides and sulfates (panel a); "Ref" indicates literature data.

\section{Discussion}

\subsection{Environmental sub-zones: stationary phenomena and runoff processes}

Throughout the years, the various Solfatara and Pisciarelli sampling sites have displayed a nearly constant mineral alteration assemblage (Table 1). Commonly, the mineral neogenesis variably develops on sub-millimeter to decimeter to meter scales, in relation to the outgassing dynamics, runoff, weather conditions, outcropping substrate and anthropogenic activity.

However, the various sites further display reproducible rock geochemistry and stable isotope compositions at the timescale of the survey and with respect to the oldest data (e.g., Valentino et al., 1999) as well; they can be considered reference points for future investigations.

Based on the presented dataset, we propose the existence of major alteration sub-zones, in which some (minor or peculiar) mineral phases appear or disappear, in response to 


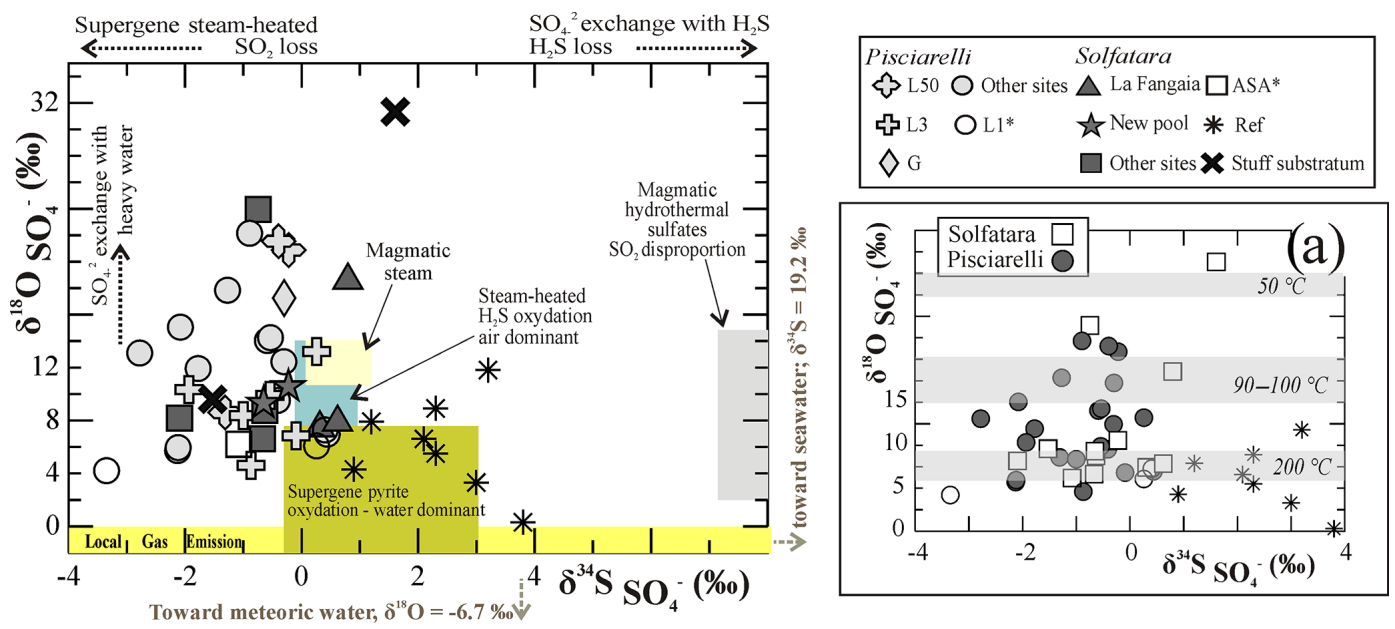

Figure 7. Covariation of $\delta^{34} \mathrm{~S}$ vs. $\delta^{18} \mathrm{O}$ values in sulfates, symbolized to distinguish the specific materials on the basis of sampling sites. Modern marine sulfate, meteoric water (in the diagram), the $\delta^{18} \mathrm{O}$ values of local gas emissions and literature data are based on Cortecci et al. (1978), Allard et al. (1991), Valentino et al. (1999), Chiodini et al. (2016), Caliro et al. (2007) and Piochi et al. (2015). $\delta^{18}$ O values of local outgassing are $-2 \%$ to $0 \%$. Fields and processes based on Rye et al. (1992) and Rye (2005). Panel (a) highlights Solfatara and Pisciarelli samples; shaded areas define the $\delta^{18} \mathrm{O}$ values we recalculated based on Rye et al. (1992) at the indicated temperature. Fields and processes based on Rye et al. (1992) and Rye (2005); "Ref" indicates literature data.
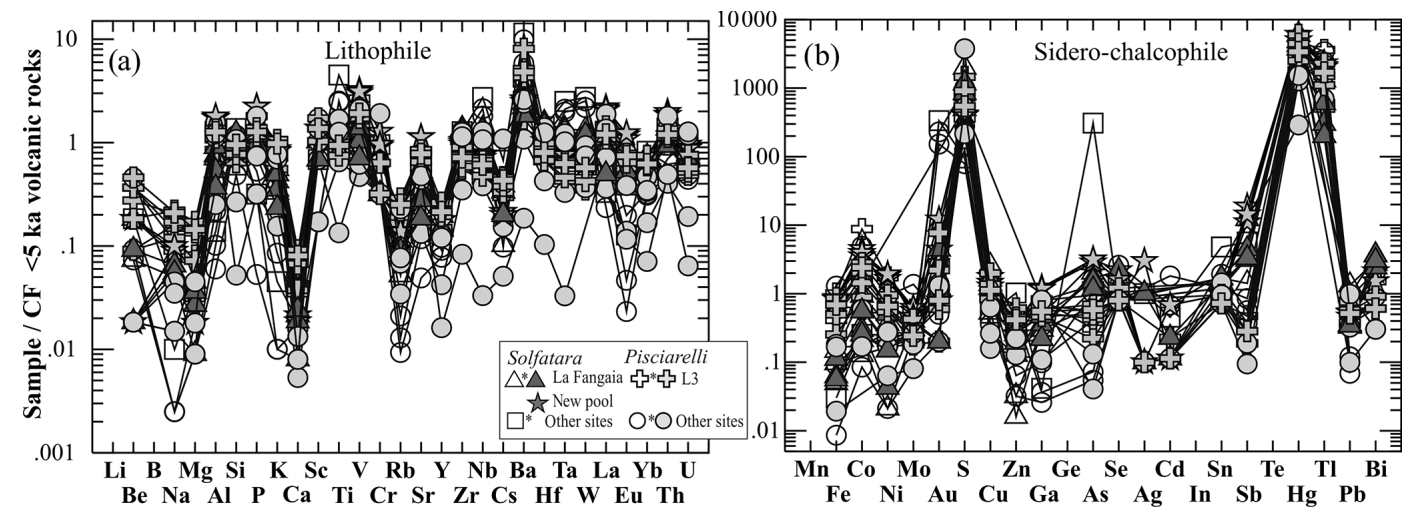

Figure 8. Lithophile (a) and sidero-chalcophile (b) element concentrations normalized with respect to the average whole-rock composition of pristine volcanic rocks with an age $<5 \mathrm{ka}$ (D’Antonio et al., 1999; Piochi et al., 2014), as those outcropping in the Puteoli sulfate areas. The asterisk $\left(^{*}\right)$ in the legend indicates other datasets (not published).

changing physical-chemical boundary conditions mainly associated with weather circumstances, i.e., mostly humidity and water abundance. These sub-zones are discriminated by their dominant and repetitive mineralogy, rock chemistry and isotopic compositions and characterized by temperature variations in a narrow range. Such a constancy is revealed when comparing results reported by Sicardi (1959) (see Geological setting in Sect. 2.1) with the present results, corroborating the existence of "stationary" sub-zones that are presented in the following. The only exception is the mud pool in the crater.

The Pisciarelli and Solfatara pools (Fig. 1d, e) are the two major and distinct sub-zones. They display persistent differences in dynamics, temperature and mud (solute plus water) mineralogy. The main pool at Pisciarelli shows vigorous boiling (Fig. 1b, e), with temperatures ranging from 63.9 to
$94.3{ }^{\circ} \mathrm{C}$ (Tables $\mathrm{S} 1$ and 2) and a relative dominance of water vapor. The mud is typically gray in color, mostly ash to sand up to millimeter-sized grains, with generally rounded or smoothed shapes as a function of the strength of boiling and the material supply from the nearby slopes. On the other hand, the main Solfatara pool is characterized by degassing with a temperature of around $49^{\circ} \mathrm{C}$ (Tables S1 and 2 ). The mud is beige and fine-grained, always with a fetid odor. We recurrently detected an enrichment in pyrite, illite and feldspar at Pisciarelli and in native sulfur at Solfatara. The latter is enriched in $\mathrm{As}, \mathrm{Hg}, \mathrm{Nb}, \mathrm{W}, \mathrm{Zr}$ and $\mathrm{Sb}$ and depleted in $\mathrm{Sr}, \mathrm{Ba}$ and $\mathrm{Co}$ compared to the original deposits (Fig. 8). Sulfides and sulfates display nearly similar $\delta^{34} \mathrm{~S}$ values at Solfatara, whereas they are different at the Pisciarelli mud pool (Fig. 6a, inset). The DRIFT-FTIR spectra of 
muds from Pisciarelli, in contrast to those from Solfatara, always gave the vibration at $1430 \mathrm{~cm}^{-1}$ related to the $\mathrm{NH}_{4}$ (see Sect. 3.1). Notably, the La Fangaia mud pool (Fig. 1d) is likely cooling as Sicardi (1959) reported up $100^{\circ} \mathrm{C}$, several tens of degrees higher than at the present (Tables S1 and 2). A slight cooling is discernible when comparing our data (Table S1) with those in the literature (Martini et al., 1991; Celico et al., 1992; Valentino and Stanzione, 2003). In contrast, the Pisciarelli area should be hotter, although only by a few degrees Celsius (Tables S1 and 2) if compared with increasing temperature values at the geyser vent (Chiodini et al., 2016).

The PINT-PEXT sub-zone (Fig. 1e) - an isolated morphological height - is composed of an alunitic-rich low-cohesive reddish terrain with a temperature of around $95^{\circ} \mathrm{C}$, typically comprising kaolinite (Tables $\mathrm{S} 1$ and 2). The kaolinite is easily discriminated also by DRIFT-FTIR spectra (not shown) that, in agreement with XRDP traces, point to a wellordered structure. This terrain bears variably sized (up to a few decimeters) clasts and is subject to slumping and sinking.

A hole up to 2-3 $\mathrm{m}$ deep represents a distinct sub-zone that we emphasize because it opened $180 \mathrm{~m}$ north of the main pool within the crater in May 2017, by surface collapse. A gray viscously boiling mud fills the hole (Fig. 1c, d), with a minimum temperature of $70^{\circ} \mathrm{C}$; a temperature of $91^{\circ} \mathrm{C}$ was measured in April 2019. The mud is dominated by alunite with subordinate native sulfur, showing vague similarity to Solfatara mud (Table S1), although its gray color and the occasional pyrite are reminiscent of the Pisciarelli mud. However, kaolinite is the main clay mineral in the new pool (Figs. S1e; S2e, note the inset). Mud geochemistry reveals peculiarly high concentrations of $\mathrm{Sr}, \mathrm{Ga}, \mathrm{Co}, \mathrm{Th}, \mathrm{V}$, REE (rare-earth elements) and $\mathrm{Sb}$ (Fig. 9a, b and Table S3).

Finally, a rather broad sub-zone includes the other various sampling sites that are characterized by encrustations of alunite with a well-defined, although relatively large, range of $\delta^{34} \mathrm{~S}$ values between ca. $-4 \%$ and $1 \%$ (Tables S1, 2; Fig. 5c). These occurrences reflect the nearby presence of vapor degassing. We suspect that those at the ASA, Monte Olibano and SSt sampling sites along the slopes of the Solfatara crater (Fig. 1a, d) are ascribable to long-lived encrustations; further investigations are useful for ascertaining whether this suspicion is correct. The minor fumarolic vents around the old baths (Sst site) seem unchanged with respect to the description by Sicardi (1959), particularly showing the occurrence of native $\mathrm{S}$ and a comparable temperature of around $95^{\circ} \mathrm{C}$. These show variable bulk-rock geochemical compositions.

Widespread alunite formation reflects the potassium and feldspar-rich rock substrate on which they develop (see Piochi et al., 2014, 2015, and references therein).

Vapor effluents around the various geysers and vents at Pisciarelli are the most important factors affecting the mineral neogenesis at the alunite-dominated sub-zones. Piscia- relli is a decameters-deep incision on the NE Solfatara slope, and the degassing vents are constrained in a gorge-like morphology. This setting favors the stagnation of the hydrothermal steam that impregnates the rock substratum and supplies elements to the formation of a variety of $\mathrm{Na}$ and $\mathrm{NH}_{4}$ sulfates. We detected a high abundance of those phases around the pool as desiccation during the summer season. The $\mathrm{NH}_{4}^{+}$ ions were present in solution and, possibly, as droplets in the humid air, as revealed by experimental desiccation tests of the water. Aerosol particles from inside and nearby the Solfatara crater that bear $\mathrm{NH}_{4}^{+}$(and $\mathrm{Cl}^{-}$, possibly in the form of $\mathrm{NH}_{4} \mathrm{Cl}$ ) as a major ion (Mather et al., 2004), as well as the $\mathrm{NH}_{4} \mathrm{Cl}$ inside the $\mathrm{BG}$ and $\mathrm{BN}$ orange-yellow encrustations (Fig. 3g, h), furthermore support the widespread presence of ammonium species. Notably, $\mathrm{N}_{2}$ is emitted at the main intracrater fumarole of Bocca Grande (see Chiodini et al., 2010). DRIFT-FTIR and XRDP patterns (Figs. S2d, S1a, S1d), however, point to the presence of $\mathrm{NH}_{4}$ in both the mud and water pools at Pisciarelli but not at Solfatara (except for BG and $\mathrm{BN})$. Alum-(K) has also been found in relation to the wet conditions at Pisciarelli.

Vapor emission outflow and the conditions of hydrothermal steam stagnation are dependent on atmospheric pressure and wind conditions.

It is thus likely that the meteoric weather is the main cause for the appearance and disappearance (and vice versa) of some phases.

This is also particularly evident for the PINT, PEXT, L19 and L20 (Fig. 1e) and the SMO, ASA and SSt (Fig. 1d) subzones that may typically present bipyramid and/or fine dendritic sulfur crystallites (Fig. 2a). Their crystallization seems to be favored by relatively strong exhalations and porous terrain (PINT, PEXT, L19, L20; Fig. 1e) or conditions where gases remain briefly trapped (SMO, some places along ASA, Sst; Fig. 1d). Respective conditions also prevail in close proximity (< decimeter scales) to the main fumaroles (L1 vent, BG, BN; Fig. 1d, e), where sulfur forms a cream-like patina reflecting the condensing gas flow along the host fractures and fissures.

However, native $\mathrm{S}$ disappears during runoff, and we have macroscopically determined at several places that recrystallization needs 1-2 months, if not longer (i.e., sample L20 camino; Fig. 1e).

Furthermore, periods of intense rainfall determine the timing areal extent and depth of the mud pools, as well as the generation of secondary mud vents and the erosion in Pisciarelli and its periodic water puddle. Sicardi (1959) already noted the occurrence of mud vents and black mud pools following rainy periods. Notably, pools at Pisciarelli are supported by anthropogenic embankment.

Meteoric and surface waters can dilute the aggressive endogenous fluids determining alteration degree conditions low enough for the generation of illite, or other clays (Pirajno, 2008) at Pisciarelli. Further studies need to be performed in 


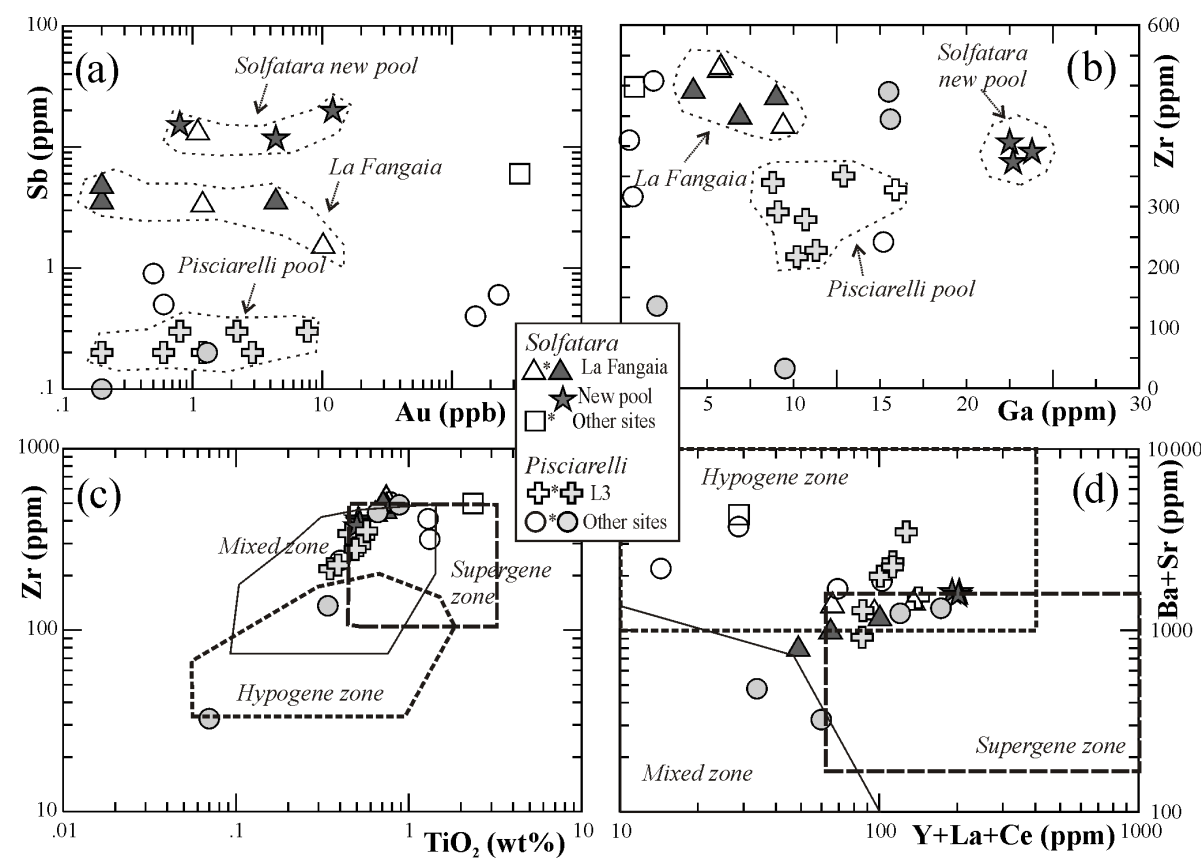

Figure 9. Cross plots of trace elements in solfataric samples. Fields envelop the various genetic settings, following Ercan et al. (2016) and based on the (a) immobile and (b) and mobile elements sourced from K-feldspars ( $\mathrm{Ba}, \mathrm{Sr}, \mathrm{Ce}, \mathrm{Y}, \mathrm{La})$, in an initially alteration-undersaturated geothermal solution. Note the logarithmic scale in (a), (c) and (d).

order to better characterize clays as they can bear information useful to further constrain the hydrothermal setting.

$\mathrm{Al}$ and $\mathrm{Fe}$ sulfates (halotrichite) have been rarely found nearby the Pisciarelli geyser (see G in Fig. 1e; Tables 1, S1).

The distribution of sulfates appears irregular, and this should be an subject of future investigations.

\subsection{Classification of alteration and genetic environments: contradictory data}

The style of mineralization (Arribas, 1995; Sillitoe, 1993; Pirajno, 2008; Ercan et al., 2016) and the stable isotope results (Rye et al., 1992) allow the classification of alteration and differentiation of genetic environments. Table 3 summarizes characteristic mineralogical, lithological and isotopic features of these environments, in comparison to observations made at the study sites. Several contrasting interpretations can result from the data.

Alunite plus kaolinite form in steam-heated environments at 100 to $160^{\circ} \mathrm{C}$, where fumarolic vapor condenses above the boiling zone of nearly neutral-pH, $\mathrm{H}_{2} \mathrm{~S}$-rich fluids representing a low sulfidation environment.

Nevertheless, alunite shows grain sizes in the range of 50 to $100 \mu \mathrm{m}$ (Fig. 3e, f), unlike the finest $(<20 \mu \mathrm{m})$ ones detected in high-temperature $\left(>40-50{ }^{\circ} \mathrm{C}\right)$ steam-heated (Simón et al., 2005) or supergene (Arribas, 1995) environments. Those coarser sizes usually occur in low-temperature steam-heated (and hypogene, as well) environments (Hedenquist et al., 2000) or could directly crystallize from a $\mathrm{SO}_{2}$ - rich magmatic vapor that rapidly ascend through fractures (namely high-sulfidation setting; Rye et al., 1992; Stoffregen and Alpers, 1992). The occurrence of kaolinite and alunite at several Solfatara and Pisciarelli sub-zones (particularly, new pool and PINT; Table 1) fits with the high-sulfidation environment; in fact, the two phases usually coexist in the advanced argillic alteration zone proxy to ascent plumes (e.g., Pirajno, 2008). The evidence of K-feldspar replacement by alunite (Piochi et al., 2015), the disseminated pyrite and the presence of native $S$ at Pisciarelli apparently support the classification as a high-sulfidation-magmatic-hydrothermal environment (Rye et al., 1992). Nevertheless, illites or montmorillonites are most common in intermediate argillic alteration zones (Pirajno, 2008), and their widespread occurrence in the various studied sites, as well as in the local subsurface (Valentino and Stanzione, 2003, 2004), is among the results that contrasts with this high-sulfidation environment. Indeed, sampling temperatures are higher than $40{ }^{\circ} \mathrm{C}$ (Tables 2 and $\mathrm{S} 1$ ) and $\mathrm{SO}_{2}$ is rare or absent (Aiuppa et al., 2013) at Campi Flegrei. Also, the lack (or rare detection) of lower-temperature $\left(<40^{\circ} \mathrm{C}\right)$, disordered polymorphs (i.e., halloysite) point to limited supergene alteration.

Only the alunite coexisting with kaolinite in the new hole pool exhibits the finest grain size. Accordingly, the XRDP and DRIFT-FTIR analyses of CF samples point to slightly ordered kaolinite forms that usually occur at temperatures $<150^{\circ} \mathrm{C}$ in epithermal systems (Sillitoe, 1993) but could also represent a metastable form in hotter settings (Zotov et al., 1998). In this latter case, the new pool sub-zone with 


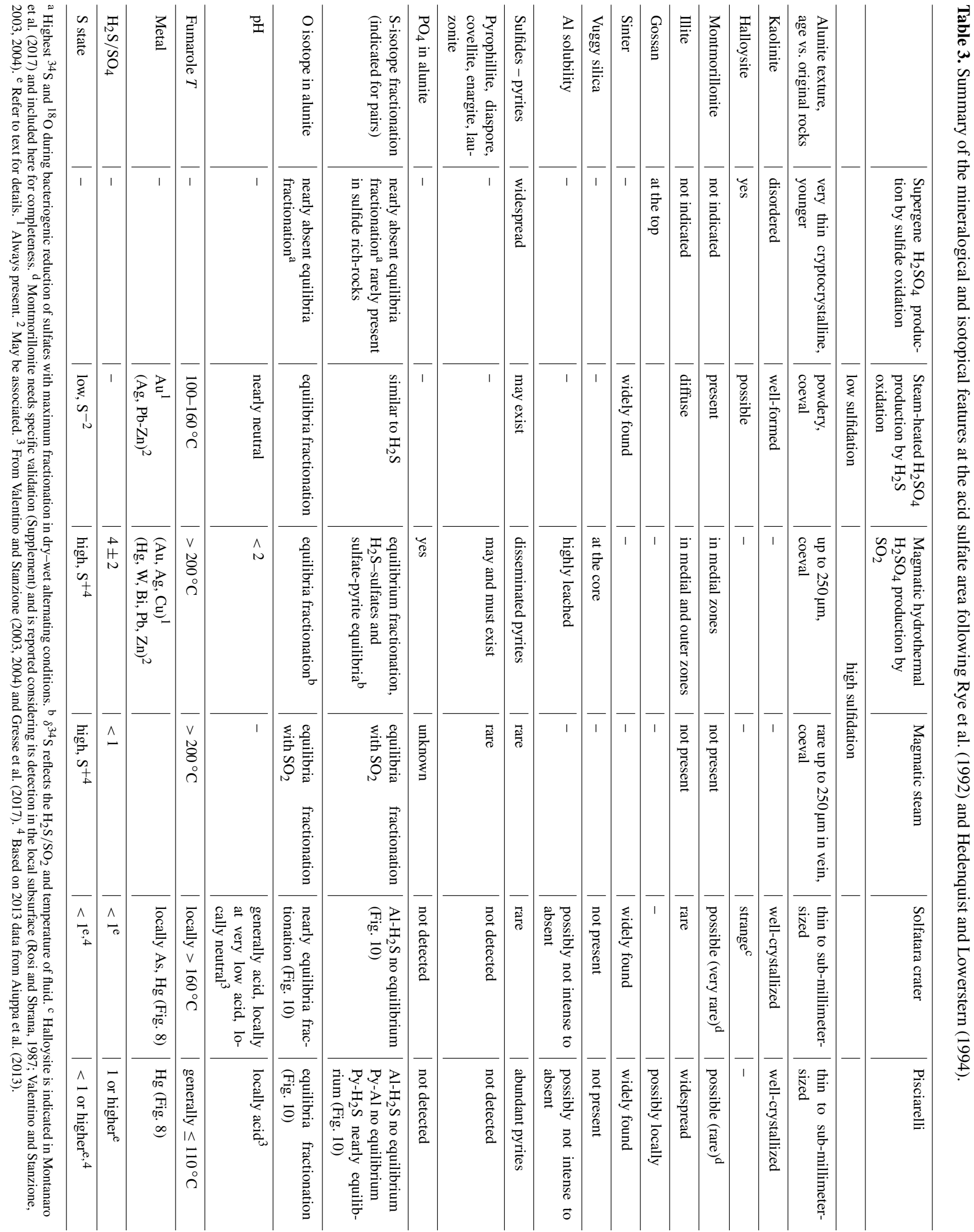


kaolinite and alunite can represent local, well-circumscribed advanced argillic alteration conditions indicative of a proxy plume.

However, when considering litho-geochemical parameters, schematic diagrams further produce contrasting visions. For example, following Ercan et al. (2016), the clay-bearing muds can be ascribed to a variable supergene to hypogene alteration field in the binary diagram of immobile $\mathrm{Zr}$ vs. $\mathrm{TiO}_{2}$ (Fig. 9c). They also have high (above $1000 \mathrm{ppm}$ ) $\mathrm{Ba}+\mathrm{Sr}$ and low $(<200 \mathrm{ppm}) \mathrm{Ce}+\mathrm{Y}+$ La concentrations (Fig. 9d).

The stable isotope geochemistry of minerals supports an interpretation of steam-heated to supergene environments (Fig. 7). S-isotope equilibrium occurs between sulfides and sulfates, with reliable re-calculated temperatures in highsulfidation environments (Arribas, 1995). In contrast, this equilibrium cannot be accounted for at Campi Flegrei, and any reliable temperatures result from the $\mathrm{S}$-isotope fractionation between sulfates and $\mathrm{H}_{2} \mathrm{~S}$. In fact, $\delta^{34} \mathrm{~S}$ values of alunite and pyrite roughly overlap. Instead, sulfur- $\mathrm{H}_{2} \mathrm{~S}$ and sulfide$\mathrm{H}_{2} \mathrm{~S}$ pairs at the sampling temperature reflect equilibrium $\mathrm{S}$ isotope fractionation: the theoretical $\delta^{34} \mathrm{~S}$ value of dissolved $\mathrm{H}_{2} \mathrm{~S}$ fluid is between $-3.84 \%$ and $-0.84 \%$ (Allard et al., 1991). This also implies that the sulfate-altered rocks are not magmatic hydrothermal in origin, in agreement with the lack of typical mineral phases that show a high-oxidation state of $\mathrm{S}\left(\mathrm{SO}_{2}\right.$-rich, high sulfidation according to Henley and Ellis, 1983). Based on Rye et al. (1992), $\mathrm{SO}_{2}$ disproportionation results in the formation of ${ }^{34} \mathrm{~S}$-enriched $\mathrm{H}_{2} \mathrm{SO}_{4}$ and ${ }^{34} \mathrm{~S}$ depleted $\mathrm{H}_{2} \mathrm{~S}$. In addition, the intense $\mathrm{Al}$ leaching in a highsulfidation system is not typical of the Campi Flegrei setting (Fig. 8; Table 3).

Actually, Campi Flegrei lacks the occurrence of enargite and luzonite, both diagnostic for high-sulfidation environments. Instead, it shows minor occurrences of realgar (AsS) as well as cinnabar (HgS) (Tables $1, \mathrm{~S} 1)$, and orpiment has also been described (Russo et al., 2017).

Significantly lower $\delta^{34} \mathrm{~S}$ values $(<15 \%$ ) for alunite can derive from (i) the light sulfur isotopic composition of $\mathrm{H}_{2} \mathrm{~S}$ during boiling (steam-heated or low-sulfidation setting), (ii) $\delta^{34} \mathrm{~S}$ of sulfides (supergene) or (iii) the bulk sulfur isotope composition of magmatic steam (Rye et al., 1992). The first possibility could partly account for the isotopic composition of alunite-pyrite and alunite- $\mathrm{H}_{2} \mathrm{O}$ pairs (Fig. 10), although contrasting with conclusions based on texture, mineral assemblage and bulk-rock geochemistry (Table 3). The presence of kaolinite in the subsurface, under an alunitic cover, and the occurrence of argillic alteration at depth suggest a vertical zonation at the Solfatara crater and, following Rye et al. (1992), a steam-heated setting.

Furthermore, $\delta^{34} \mathrm{~S}$ values for the pyrite- $\mathrm{H}_{2} \mathrm{~S}$ pairs further support a supergene setting (Fig. 10).

Finally, we are not able to directly identify any microbial sulfur cycling, although FTIR and rock geochemistry corroborate the absence of or limited biota contribution. The analyzed samples do not exhibit bands attributable to $\mathrm{C}=\mathrm{H}$ lig-

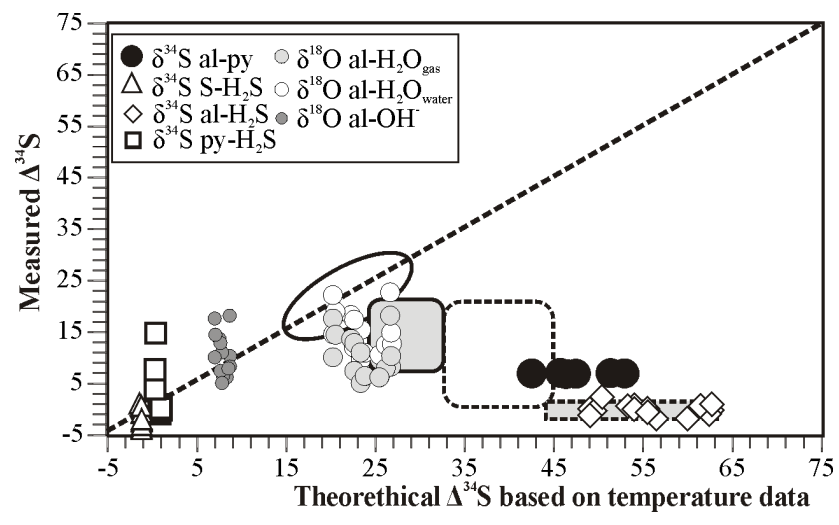

Figure 10. Measured vs. theoretical fractionation values. Theoretical values based on temperature measurements were calculated following Ohmoto and Rye (1979) and Rye et al. (1992). Fields for steam-heated (white) and supergene (gray) environments are from Rye et al. (1992): dashed envelop for alunite-pyrite (circle) or alunite- $\mathrm{H}_{2} \mathrm{~S}$ (rhombus) pairs, continuous envelop for alunite- $\mathrm{H}_{2} \mathrm{O}$.

ands (Supplement), and the carbon content is $<1.25 \mathrm{wt} \%$ (most common $<0.2 \mathrm{wt} \%$; Table S3). Yet, some higher $\delta^{34} \mathrm{~S}$ and $\delta^{18} \mathrm{O}$ values for sulfates could be indicative of microbial sulfur cycling, particularly considering the dry-wet alternating conditions.

\subsection{Merging information and unraveling the setting}

Merging all available information, it appears that observations concerning both the apparent "stationarity" at subzones and a seemingly contradictory classification environment reflect the evolving conditions that have followed the last magma intrusion and eruption and that probably are overlapping through time.

The solfataric alteration zone has a strongly limited extent within the central sector of the Campi Flegrei caldera. It coincides with the area of eruptive vents (e.g., Mt. Olibano, Accademia, Solfatara; Fig. 1a) and uplift of the most recent period of volcanism (Di Vito et al., 1999). The zone appears to be limited under the later Fossa Lupara and Astroni vents, while outgassing and thermal aquifers occur within the caldera. However, there is an indication for their discrete, more than their continuous distribution, both across the caldera and through depth (Guglielminetti, 1986).

The studied deposits are young and nearly coeval $(<5000$ years $)$ with the altered volcanic basement deposits (i.e., Monte Olibano, Solfatara).

The alteration zone locally presents high $\mathrm{Ti}, \mathrm{Ba}, \mathrm{Au}, \mathrm{As}$, $\mathrm{Hg}, \mathrm{Tl}$ and $\mathrm{S}$ concentrations relative to the above parent basement lithology (Fig. 8).

The zone also appears anomalous in terms of ammonium content. Therefore, we here adopt ammonium as a possible tracer, but we have no information yet about the various contributing sources for the $\mathrm{N}$ species and the cycling of nitrogen at the local scale. The presence of $\mathrm{NH}_{4}$-bearing sulfates 
is particularly abundant at Pisciarelli. Those sulfates systematically form by drying water collected at the various pools of the area, in relation to the abundance of nitrogen species $\left(0.2-1 \mathrm{~g} \mathrm{~L}^{-1}\right)$ in those waters (Martini et al., 1991; Celico et al., 1992; Valentino et al., 1999; Holloway and Dahlgren, 2002; Valentino and Stanzione, 2003, 2004; Aiuppa et al., 2006). Actually, the $\mathrm{NH}_{4}^{+}$content in the shallowest Phlegraean groundwater is generally low $\left(<0.03 \mathrm{~g} \mathrm{~L}^{-1}\right.$; Martini et al., 1991; Celico et al., 1992; Valentino et al., 1999; Valentino and Stanzione, 2004; Aiuppa et al., 2006). Yet, Mather et al. (2004) measured a significant abundance of ammonium chloride particles or aerosols at the Solfatara crater. Some realgar encrustations sampled at BG and BN also associate with $\mathrm{ClNH}_{4}$ (Table S1; Fig. 3g, h).

The concentration of some metals and metalloids requires sources different from the parent basement. Anthropogenic contributions are obviously possible (Alloway, 2013), e.g., when considering that $\mathrm{NH}_{4}$ is generally attributed to agricultural (i.e., fertilizer) and urban soils. However, $\mathrm{Hg}$ and As have been detected at the main fumaroles with similar concentrations today and in the last century (Ferrara et al., 1994; Bagnato et al., 2014). These fumaroles continuously emit $\mathrm{H}_{2} \mathrm{~S}$ and $\mathrm{CO}_{2}$ (Allard et al., 1991; Aiuppa et al., 2013; Chiodini et al., 2016) and are the preferred location of the crystallization of native $\mathrm{S}$ and alunite. $\mathrm{NH}_{4}^{+}$emissions are also present at Solfatara (Chiodini et al., 2010), although ammonium is of limited importance inside the crater waters $\left(<0.001 \mathrm{~g} \mathrm{~L}^{-1}\right.$; Aiuppa et al., 2006) and the crystallization of alum instead of $\mathrm{NH}_{4}^{+}$sulfates has been obtained in the water from Solfatara pool. In agreement with these authors, the plausible source is the conventional geothermal reservoir.

High concentrations $\left(20-100 \mathrm{~g} \mathrm{~L}^{-1}\right)$ of ammonium are reported in the deeper (> $500 \mathrm{~m}$; Carlino et al., 2012) aquifers at the Mofete wells, located on the western side of the Campi Flegrei (Chiodini et al., 1988). Those deeper aquifers are located within a sequence of tuffs and marine sediments also drilled by the CF23 well (1000-1200 m depth; Piochi et al., 2014, 2015), i.e., nearby the solfataric area.

In summary, we propose an environmental setting that merges all collected information (Fig. 11). Fluid outflows from discrete aquifers hosted in sediments - and bearing organic imprints - feed the Pisciarelli site giving its ammonium peculiarity. Our purpose does not exclude the possible biological contribution that has been ascertained in the studied sites (e.g., Ciniglia et al., 2005; Glamoclija et al., 2004). However, marine strata and a volcano-clastic sequence intercepted by deep drillings (San Vito1, Mofete and CF23 wells; Rosi and Sbrana, 1987; Piochi et al., 2014) are considered as the key sediments for the $\mathrm{NH}_{4}$ species. An additional supply can originate from the swampy sediments encountered in shallowest boreholes (de Vita et al., 1999) located in the central sector of the caldera (Fig. 11), nearest to the study area. Results from cluster analysis of resistivity, P-wave velocity and density parameters from Pisciarelli across the Solfatara crater (Di Giuseppe et al., 2017) lithologically con- strain the model section. These authors highlight a sudden uprise to ca. $1500 \mathrm{~m}$ depth of buried rocks through a tectonic structure just beneath Pisciarelli. The dislocated rocks are the fossiliferous marine and volcano-clastic sequences drilled across the caldera. The deep aquifer is represented by a confined body with a high electrical conductibility $(\log \rho=$ $0.97 \Omega \mathrm{m})$. At the deepest position in the model, we correlate thermo-metamorphic rocks with the brines characterized by $\log \rho$ at $2.7 \Omega \mathrm{m}, \mathrm{Vp}=3800 \mathrm{~m} \mathrm{~s}^{-1}$ and $\Delta \sigma-38.8 \mathrm{~kg} \mathrm{~m}^{-3}$. These physical features are indicative of the occurrence of voids/fracturing and the migration of gases. Therefore, we infer a deep source of gases emitted at the surface, which likely also indicates the location of the heat source.

Shallow and deeper aquifers are interconnected via a network of "communicating vessels" through a fault system, allowing deeper and shallower water to mix and be expelled at Pisciarelli. This justifies an apparent persistence of thermal springs around the Agnano Plain also in the presence of the desiccating lake described by Ventriglia (1942). It also supports the depth of the water table, being at a higher topographic position in the Solfatara area with respect to the surroundings (Bruno et al., 2007).

In the model, we further speculate that the acid sulfate alteration zone at the Campi Flegrei is actually evidence of a paleo-conduit. This is based on field observations showing that alteration deposits locally underlie the most recent eruptive units (e.g., Astroni) that are unaltered moving away from the acid sulfate zone. Therefore, the texture of the mineral assemblage, the enrichment in some metals and the lithogeochemical parameters are a relict of a "high-sulfidation system". The evolutionary dynamics within the conduit and, in particular, the water overflows from the aquifers alternating with runoff processes explain the contradictory mineral environments with superimposed intermediate and advanced argillic alteration.

At present, a steam-heated (or low-sulfidation) environment (as derived by most isotope data on alunites; see previous section) is developing in relation to the presence of aquifers and their chemical compositions. This is in agreement with previous studies (e.g., Aiuppa et al., 2006; Piochi et al., 2015; Gresse et al., 2017). Following Hedenquist and Lowenstern (1994), this is also in agreement with the shift in $\delta^{18} \mathrm{O}$ at constant $\delta^{2} \mathrm{H}$ values of the emitting fluids (Caliro et al., 2007). Based on the $\delta^{18} \mathrm{O}$ values of alunite, the recalculated environmental temperature is $\leq 200^{\circ} \mathrm{C}$ (Fig. 8, shaded areas in panel a).

Furthermore, the presence of $\mathrm{NH}_{4}^{+}$is considered strictly connected to the surface environment and likely to organic or biological processes (Jaffe, 2000), which is consistent with $\mathrm{S}$-isotope values of pyrite- $\mathrm{H}_{2} \mathrm{~S}$ pairs, the heavier $\delta^{34} \mathrm{~S}$ values suggesting microbial sulfur cycling and a supergene environment that is locally developing. 


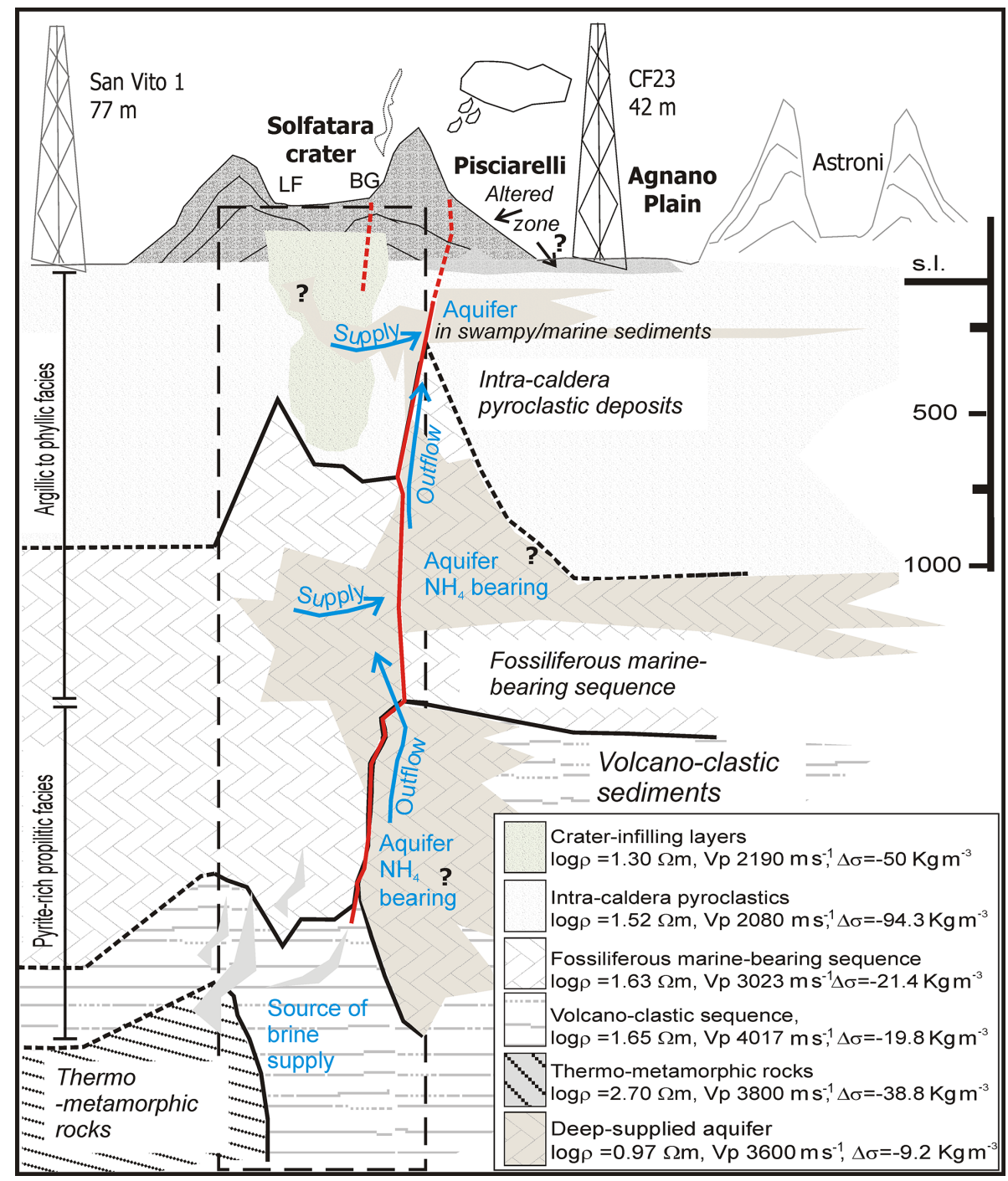

Figure 11. Sketch of the acid sulfate alteration zone at the Campi Flegrei caldera (Fig. 1a). The subsurface is constrained by borehole (deep from Rosi and Sbrana, 1987; Piochi et al., 2014, and shallow from de Vita et al., 1999) and geophysics (Di Giuseppe et al., 2017) information. The presence of $\mathrm{NH}_{4}$-rich aquifers correlates with their occurrence in marine sequences (Rosi and Sbrana, 1987; Piochi et al., 2014) at the

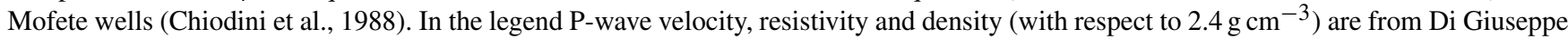
et al. (2017); the geophysically explored area is in the dashed rectangle. BG - Bocca Grande (Fig. 1d); LF - La Fangaia mud pool (Fig. 1a, d).

\section{Conclusions and outlook}

The acid sulfate alteration zone at Pisciarelli and Solfatara is located in the sector of the Campi Flegrei caldera that has been the most volcanically active area in the last $5 \mathrm{kyr}$. The alteration zone includes discrete sub-zones with very constant mineralogy, temperature and chemistry, considering the studied time interval. Outgassing dynamics, weather conditions and runoff are the most important factors affecting the generation of new mineral phases at the sub-millimeter to decimeter to meter scales.

The new minerals include alunite, alunogen, native sulfur, pyrite, kaolinite and subordinately mascagnite.
The limited areal extent of the alteration zone underlying the most recent unaltered volcanic units, its mineralization texture and style, the $\delta^{18} \mathrm{O}$ and $\delta^{34} \mathrm{~S}$ values of S-bearing minerals, and the enrichment in $\mathrm{Ti}, \mathrm{Ba}, \mathrm{Au}, \mathrm{As}, \mathrm{Hg}$ and $\mathrm{Tl}$ are attributed to the evolution of a paleo-conduit. Our mineralogical and isotopical results overlap with those in Valentino et al. (1999), favoring a stability in the hydrothermal dynamics over the past 20 years. The zone is anomalous in terms of the presence of $\mathrm{NH}_{4}^{+}$. These features result from the mixing between waters that overflow through a fault system intercepting discrete aquifers supplied by surface water and deep fluids. Most of the alunite forms above the water table at a tem- 
perature $\leq 200^{\circ} \mathrm{C}$. At present, the dominant steam-heated environment coexists with local supergenic conditions.

Based on presently available data, several key aspects await further investigations.

In particular, a detailed survey of the distribution of aquifers in the subsurface will foster our understanding of caldera dynamics and contribute to the debate existing between a "hydrothermal" (Moretti et al., 2017) vs. a "magmatic" (Cardellini et al., 2017) unrest. Assessing the composition and spatial extent of aquifers - also including the contribution from rainfall - is crucial in solving the nonmagmatic role in processes at the surface. Soluble acid components $\left(\mathrm{SO}_{2}, \mathrm{HCl}\right.$ and $\left.\mathrm{HF}\right)$ sourced at depth are condensing in the shallower aquifer system (Valentino and Stanzione, 2003; Aiuppa et al., 2006; Caliro et al., 2007; Vaselli et al., 2011; Piochi et al., 2014, 2015; Chiodini et al., 2016). However, the ability to buffer these magmatic fluids clearly depends on the water availability in relation to the volume of juvenile fluid, with implications on the sourced magma volume(s) evolving or degassing at depth. On the other hand, the circulation of fluids in the subsurface, sourced from both the downward surface infiltration and the ascent of deep fluids, would contribute to the pressurization that is evident through shallow seismicity as previously suggested (Saccorotti et al., 2007; D'Auria et al., 2011; Di Luccio et al., 2015). Most important, knowing the water availability in the subsurface is crucial for evaluating the volcanic hazard in an area dominated by phreatomagmatic events, such as the Campi Flegrei caldera (Rosi and Sbrana, 1987; Di Vito et al., 1999).
What causes the presence of $\mathrm{NH}_{4}^{+}$is still rather elusive. Based on Moretti et al. (2017), it appears useful for evaluating the temperature dependence of $\mathrm{N}_{2}$ vs. ammonia production and the relative role of hydrothermal vs. magmatic systems. We add the possible role of organic materials and bacteria and atmospheric sources to the terrestrial cycle. Furthermore, ammonia $\mathrm{NH}_{3}$ is toxic (Fromm and Gillete, 1968), and this requires ascertaining its concentration level in an inhabited environment.

Finally, the Pisciarelli site appears suitable for studies related to biota and the origin and evolution of life. Here, the water dominance, nitrogen richness, $\leq 200^{\circ} \mathrm{C}$ temperatures and supergenic conditions are all considered important ingredients for the formation of organic substances and the ultimate source of organisms (Jaffe, 2000). Consequently, this site could become a natural laboratory for investigating the complex organic-inorganic interface or relations through multidisciplinary collaborations among mineralogists, geochemists, petrologists, volcanologists and biologists.

Data availability. Our dataset is in Tables 2 and S1, S2 and S3 in the Supplement. 


\section{Appendix A}

XRDP and DRIFT-FTIR patterns were acquired at the Osservatorio Vesuviano (Istituto Nazionale di Geofisica e Vulcanologia, Naples, Italy).

The XRDP instrument was a PANalytical X'Pert equipped with a high speed PIXcel detector (Mormone et al., 2014). The configuration includes an $\mathrm{Ni}$ filter, $\mathrm{CuK} \alpha$ radiation, a pyrolytic graphite crystal monochromator, $40 \mathrm{kV}$ and $40 \mathrm{~mA}$ current, $3-70^{\circ}, 2 \theta$ range, $0.02^{\circ}$ steps and $8 \mathrm{~s}$ per step. The X'Pert HIGH Score Plus computer program and JCPDS PDF-2 database allowed the interpretation of diffraction patterns.

DRIFT was mounted on a Nicolet 670 NexusTM, both by ThermoFisher Scientific S.p.a. (Società per Azioni). The FTIR comprises a heated ceramic (Globar) source, a 670 laser unit, a $\mathrm{KBr}$ beam splitter and an MCT (mercury, cadmium, telluride) detector, constantly purged from a highpressure Nitrox dry air and $\mathrm{CO}_{2}$-trapping 280 generator by Domnick Hunter. The OMNIC Data Collector 5.2@ allows data collection and interpretation in the investigated range of 5000-400 $\mathrm{cm}^{-1}$ (resolution: $<0.1 \mathrm{~cm}^{-1}$ ). Data collection was conducted on $\mathrm{KBr}$ mixed with $5 \%-10 \%$ of sample by grinding in an agate mortar, following the background acquisition for the $\mathrm{KBr}$ powder. Additional acquisition on no diluted samples allowed checking for possible hygroscopic effects, obtaining similar results.

The appearance, morphology and chemical composition of minerals were determined on selected samples prepared as opaque mounts coated by cord and rod graphite, in JEOL and ZEISS electron microscope (EDS-BSEM) facilities. The JEOL-JSM 5310, equipped with a Link EDS and Inca 4.08 software (CISAG Laboratory University of Napoli Federico II), has operating conditions of $15 \mathrm{kV}$ accelerating voltage, 50-100 mA filament current, variable spot size and $50 \mathrm{~s}$ net acquisition time. The ZEISS instrument is a SIGMA field emission scanning electron microscope (Osservatorio Vesuviano, Istituto Nazionale di Geofisica e Vulcanologia, Naples, Italy), equipped with an XMAN micro-analysis system by Oxford, controlled by SMARTSEM and AZTEC softwares. Operating conditions for SIGMA were $15 \mathrm{kV}$ accelerating voltage, $50-100 \mathrm{~mA}$ filament current, $5-10 \mathrm{~nm}$ spot size and variable acquisition time (several to tens of seconds). The ZEISS microscope allowed acquiring images in Fig. 3.

WRG was carried out at Bureau Laboratories Ltd. (Vancouver, Canada). Major elements were analyzed by an inductively coupled plasma emission spectrometer (ICP-ES) using $\mathrm{LiBO}_{2} / \mathrm{Li}_{2} \mathrm{~B}_{4} \mathrm{O}_{7}$ fusion; minor and trace elements were determined by inductively coupled plasma mass spectrometry (ICP-MS) using a four-acid $\left(\mathrm{HNO}_{3}-\mathrm{HClO}_{4}-\mathrm{HF}-\mathrm{HCl}\right)$ digestion. The uncertainty is generally $<1 \%$ for major/minor oxides and $<5 \%-20 \%$ for trace elements. A LECO induction furnace was used for determining the $\mathrm{C}$ and $\mathrm{S}$ abundances. LOI was calculated by weight loss after ignition at $1000^{\circ} \mathrm{C}$.
Sulfur and oxygen isotope measurements were performed directly on pure mineral separates without and with further chemical preparation in the stable isotope laboratory at the Institut für Geologie und Paläontologie (University of Münster). Chemical preparation was different depending on sample type: i.e., sulfates + elemental $\mathrm{S}+$ sulfides, elemental S + sulfides, or muds. Oxidized S-bearing and multiphase samples first required the extraction of sulfate by sample leaching in a $10 \% \mathrm{NaCl}$ solution and filtration through a $0.45 \mu \mathrm{m}$ (pore size) cellulose acetate filter and were followed by the addition of $8.5 \%$ barium chloride solution to precipitate dissolved sulfate as barium sulfate for isotope measurements. Elemental S and pyrite extraction was performed on sulfate-free powders. This extraction consisted of a wet chemical treatment (acidic chromous chloride solution at sub-boiling conditions) that liberates sulfur as hydrogen sulfide, which will ultimately be precipitated as silver sulfide, ready for isotope measurements. Elemental sulfur was liberated from each sample via acetone leaching and subsequently converted to silver sulfide, applying the acidic chromous chloride treatment (Canfield et al., 1986). Again, resulting hydrogen sulfide was precipitated as silver sulfide $\left(\mathrm{Ag}_{2} \mathrm{~S}\right)$. For $\mathrm{S}$-isotope measurements, mineral separates as well as silver sulfide and barium sulfate precipitates were homogenously mixed with vanadium pentaoxide in tin capsules and combusted in a Carlo Erba elemental analyzer interfaced with a ThermoFinnigan Delta Plus mass spectrometer (EAIRMS: elemental analyzer isotope ratio mass spectrometry). Results are reported in the standard delta notation $\left(\delta^{34} S\right)$ as per mil difference to the Vienna Canyon Diablo Troilite (VCDT) standard. Reproducibility as determined through replicate measurements was generally better than $\pm 0.3 \%$. Sulfates were also measured for $\mathrm{O}$ isotopes by using a ThermoFinnigan TC/EA (high-temperature conversion elemental analyzer) interfaced with a ThermoFinnigan Delta Plus XL. Results are reported in the standard delta notation $\left(\delta^{18} \mathrm{O}\right)$ as per mil difference to the Vienna Standard Mean Ocean Water (VSMOW) standard. Reproducibility as determined through replicate measurements was generally better than $\pm 0.5 \%$. 
Supplement. The supplement related to this article is available online at: https://doi.org/10.5194/se-10-1809-2019-supplement.

Author contributions. MP and AM conducted sampling campaigns and prepared samples for analyses. GB participated in some of the sampling campaigns. AM conducted the XRPD analyses and interpreted the patterns. MP acquired, elaborated on and interpreted the DRIFT-FTIR spectra and, in collaboration with AM and GB, performed the EDS-BSEM investigations. HS determined the stable isotope values and contributed to data elaboration; MP did data representations and stable isotope data modeling. MP prepared the paper. All authors contributed to the final paper.

Competing interests. The authors declare that they have no conflict of interest.

Acknowledgements. Osservatorio Vesuviano (Istituto Nazionale di Geofisica e Vulcanologia) funded analyses of whole-rock geochemistry; we are therefore grateful to the directors, namely Giuseppe De Natale and Francesca Bianco. We are also grateful to colleagues at the Osservatorio Vesuviano: Rosario Avino is kindly thanked for BG/BN sample collections in 2018. Enrica Marotta and Pasquale Belviso provided the thermos-probe. Giorgio Angarano, the Tennis Hotel and Stufe di Nerone allowed the free access at the sampling sites. We appreciated comments and suggestions from Franco Pirajno and an anonymous reviewer that improved the data presentation and discussion. We would also like to thank the Editor Kei Ogata and editorial staff for managing this paper.

Financial support. This research has been supported by the INGV (grant no. FIRS 08-6-5-056 to Monica Piochi).

Review statement. This paper was edited by Kei Ogata and reviewed by Franco Pirajno and one anonymous referee.

\section{References}

Aiuppa, A., Avino, R., Brusca, L., Caliro, S., Chiodini, G., D’Alessandro, W., Favara, R., Federico, C., Ginevra, W., Inguaggiato, S., Longo, M., Pecoraino, G., and Valenza, M.: Mineral control of arsenic content in thermal waters from volcano-hosted hydrothermal systems: Insights from island of Ischia and Phlegrean Fields (Campanian Volcanic Province, Italy), Chem. Geol., 229, 313-330, https://doi.org/10.1016/j.chemgeo.2005.11.004, 2006.

Aiuppa, A., Tamburello, G., Di Napoli, R., Cardellini, C., Chiodini, G., Giudice, G., Grassa, F., and Pedone, M.: First observations of the fumarolic gas output from a restless caldera: Implications for the current period of unrest (2005-2013) at Campi Flegrei, Geochem. Geophy. Geosy., 14, 4153-4169, https://doi.org/10.1002/ggge.20261, 2013.
Allard, P., Maiorani, A., Tedesco, D., Cortecci, G., and Turi, B.: Isotopic study of the origin of sulfur and carbon in Solfatara fumaroles, Campi Flegrei caldera, J. Volcanol. Geoth. Res., 48, 139-159, https://doi.org/10.1016/0377-0273(91)90039-3, 1991.

Alloway, B. J.: Heavy metals in soils: Trace Metals and Metalloids in Soils and their Bioavailability, Springer Dordrecht Heidelberg New York London, 613 pp., https://doi.org/10.1007/978-94-0074470-7, 2013.

Arribas, A.: Characteristics of high-sulfidation epithermal deposits, and their relation to magmatic fluid, in: Magmas, fuids and ore deposits, edited by: Thompson, J. F. H., Min. Ass. Canada, Short Course Notes, 23, 419-454, 1995.

Bagnato, E., Barra, M., Cardellini, C., Chiodini, G., Parello, F., and Sprovieri, M.: First combined flux chamber survey of mercury and $\mathrm{CO}_{2}$ emissions from soil diffuse degassing at Solfatara of Pozzuoli crater, Campi Flegrei (Italy): Mapping and quantification of gas release, J. Volcanol. Geoth. Res., 289, 26-40, https://doi.org/10.1016/j.jvolgeores.2014.10.017, 2014.

Barberi, F., Corrado, G., Innocenti, F., and Luongo, G.: Phlegrean Fields 1982-1984: Brief chronicle of a volcano emergency in a densely populated area, Bull. Volcanol., 47, 175-185, https://doi.org/10.1007/BF01961547, 1984.

Bodnar, R. J., Cannatelli, C., De Vivo, B., Lima, A., Belkin, H. E., and Milia, A.: Quantitative model for magma degassing and ground deformation (bradyseism) at Campi Flegrei, Italy: Implications for future eruptions, Geology, 35, 791-794, https://doi.org/10.1130/G23653A.1, 2007.

Bruno, P. P. G., Ricciardi, G. P., Petrillo, Z., Di Fiore, V., Troiano, A., and Chiodini, G.: Geophysical and hydrogeological experiments from a shallow hydrothermal system at Solfatara Volcano, Campi Flegrei, Italy: Response to caldera unrest, J. Geophys. Res., 112, B06201, https://doi.org/10.1029/2006JB004383, 2007.

Caliro, S., Chiodini, G., Moretti, R., Avino, R., Granieri, D., Russo, M., and Fiebig, J.: The origin of the fumaroles of La Solfatara (Campi Flegrei, South Italy), Geochim. Cosmochim. Ac., 71, 3040-3055, https://doi.org/10.1016/j.gca.2007.04.007, 2007.

Canfield, D. E., Raiswell, R., Westrich, J. T., Reaves, C. M., and Berner, R. A.: The use of chromium reduction in the analysis of reduced inorganic sulfur in sediments and shales, Chem. Geol., 54, 149-155, https://doi.org/10.1016/00092541(86)90078-1, 1986.

Capaccioni, B. and Mangani, F.: Monitoring of active but quiescent volcanoes using light hydrocarbon distribution in volcanic gases: the results of 4 years of discontinuous monitoring in the Campi Flegrei (Italy), Earth Planet. Sc. Lett., 188, 543-555, https://doi.org/10.1016/S0012-821X(01)00338-7, 2001.

Cardellini, C., Chiodini, G., Frondini, F., Avino, R., Bagnato, E., Caliro, S., Lelli, M., and Rosiello, A.: Monitoring diffuse volcanic degassing during volcanic unrests: the case of Campi Flegrei (Italy), Sci. Rep.-UK, 7, 6757, https://doi.org/10.1038/s41598-017-06941-2, 2017.

Carlino, S., Somma, R., Troise, C., and De Natale, G.: The geothermal exploration of Campanian volcanoes: historical review and future development, Renew. Sust. Energ. Rev., 16, 1004-1030, https://doi.org/10.1016/j.rser.2011.09.023, 2012.

Celico, P.: Prospezioni idrogeologiche, Vol. I-II, Liguori, Italy, 1272 pp., 1986. 
Celico, P., Dall'Aglio, M., Ghiara, M. R., Stanzione, D., Brondi, M., and Prosperi, M.: Geochemical monitoring of the thermal fluids in the Phlegraean Fields from 1970 to 1990, Boll. Soc. Geol. Ital., 111, 409-422, 1992.

Chiodini, G., Comodi, P., and Giaquinto, S.: Ammonia and boric acid in steam and water. Experimental data from geothermal wells in the phlegrean fields, Naples, Italy, Geothermics, 17, 711-718, 1988.

Chiodini, G., Frondini, F., Cardellini, C., Granieri, D., Marini, L., and Ventura, G.: $\mathrm{CO}_{2}$ degassing and energy release at Solfatara volcano, Campi Flegrei, Italy, J. Geophys. Res., 106, 213-221, https://doi.org/10.1029/2001JB000246, 2001.

Chiodini, G., Caliro, S., Cardellini, C., Granieri, D., Avino, R., Baldini, A., Donnini, M., and Minopoli, C.: Long-term variations of the Campi Flegrei, Italy, volcanic system as revealed by the monitoring of hydrothermal activity, J. Geophys. Res., 115, B03205, https://doi.org/10.1029/2008JB006258, 2010.

Chiodini, G., Paonita, A., Aiuppa, A., Costa, A., Caliro, S., De Martino, P., Acocella, V., and Vandemeulebrouck, J.: Magmas near the critical degassing pressure drive volcanic unrest towards a critical state, Nat. Commun., 7, 13712, https://doi.org/10.1038/ncomms13712, 2016.

Ciniglia, C., Valentino, G. M., Cennamo, P., De Stefano, M., Stanzione, D., Pinto, G., and Pollio, A.: Influences of geochemical and mineralogical constraints on algal distribution in acidic hydrothermal environments: Pisciarelli (Naples, Italy) as a model site, Arch. Hydrobiol., 162, 121-142, 2005.

Clark, R. N., King, T. V. V., Klejwa, M., Swayze, G. A., and Vergo, N.: High spectral resolution reflectance spectroscopy of minerals, J. Geophys. Res.-Sol. Ea., 95, 12653-12680, https://doi.org/10.1029/JB095iB08p12653, 1990.

Clark, R. N., Swayze, G. A., Wise, R., Livo, E., Hoefen, T., Kokaly, R., and Sutley, S. J.: USGS digital spectral library splib06a: U.S. Geological Survey, Digital Data Series 231, available at: http: //speclab.cr.usgs.gov/spectral.lib06 (last access: 2 May 2018), 2007.

Corrado, G., Guerra, I., Lo Bascio, A., Luongo, G., and Rampoldi, F.: Inflation and microearthquake activity of Phlegraean Fields, Italy, B. Volcanol., 40, 169-188, https://doi.org/10.1007/BF02596998, 1976.

Cortecci, G., Noto, P., and Panichi, C.: Environmental isotopic study of the Campi Flegrei (Naples, Italy) geothermal field, J. Hydrol., 36, 146-159, https://doi.org/10.1016/00221694(78)90044-6, 1978

D’Antonio, M., Civetta, L., Orsi, G., Pappalardo, L., Piochi, M., Carandente, A., de Vita, S., Di Vito, M. A., and Isaia, R.: The present state of the magmatic system of the Campi Flegrei caldera based on a reconstruction of its behavior in the past $12 \mathrm{ka}$, J. Volcanol. Geoth. Res., 91, 247-268, https://doi.org/10.1016/S0377-0273(99)00038-4, 1999.

D’Auria, L., Giudicepietro, F., Aquino, I., Borriello, G., Del Gaudio, C., Lo Bascio, D., Martini, M., Ricciardi, G. P., Ricciolino, P., and Ricco, C.: Repeated fluid-transfer episodes as a mechanism for the recent dynamics of Campi Flegrei caldera (1989-2010), J. Geophys. Res., 116, B04313, https://doi.org/10.1029/2010JB007837, 2011.

De Natale, G., Troise, C., Mark, D., Mormone, A., Piochi, M., Di Vito, M. A., Isaia, R., Carlino, S., Barra, D., and Somma, R.: The Campi Flegrei Deep Drilling Project (CFDDP): New in- sight on caldera structure, evolution and hazard implications for the Naples area (Southern Italy), Geochem. Geophy. Geosy., 17, 4836-4847, https://doi.org/10.1002/2015GC006183, 2016.

de Vita, S., Orsi, G., Civetta, L., Carandente, A., D’Antonio, M., Deino, A., di Cesare, T., Di Vito, M. A., Fisher, R. V., Isaia, R., Marotta, E., Necco, A., Ort, M., Pappalardo, L., Piochi, M., and Southon, J.: The Agnano-Monte Spina eruption (4100 years BP) in the restless Campi Flegrei caldera (Italy), J. Volcanol. Geoth. Res., 91, 269-301, https://doi.org/10.1016/S0377-0273(99)00039-6, 1999.

De Vivo, B., Belkin, H. E., Barbieri, M., Chelini, W., Lattanzi, P., Lima, A., and Tolomeo, L.: The Campi Flegrei (Italy) geothermal system: A fluid inclusion study of the Mofete and San Vito fields, J. Volcanol. Geoth. Res., 36, 303-326, https://doi.org/10.1016/0377-0273(89)90076-0, 1989.

Di Giuseppe, M. G., Troiano, A, Patella, D., Piochi, M., and Carlino, S.: A geophysical k-means cluster analysis of the Solfatara-Pisciarelli volcano-geothermal system, Campi Flegrei (Naples, Italy), J. Appl. Geophys., 156, 44-54, https://doi.org/10.1016/j.jappgeo.2017.06.001, 2017.

Di Luccio, F., Pino, N. A., Piscini, A., and Ventura, G.: Significance of the 1982-2014 Campi Flegrei seismicity: Preexisting structures, hydrothermal processes, and hazard assessment, Geophys. Res. Lett., 42, 7498-7506, https://doi.org/10.1002/2015GL064962, 2015.

Di Vito, M. A, Isaia, R., Orsi, G., Southon, J., de Vita, S., D’Antonio, M., Pappalardo, L., and Piochi, M.: Volcanism and deformation since 12,000 years at the Campi Flegrei caldera (Italy), J. Volcanol. Geoth. Res., 91, 221-246, https://doi.org/10.1016/S0377-0273(99)00037-2, 1999.

Ercan, H. Ü., Işik, E. Ö., Schroeder, P. A., and Karacik, Z.: Differentiating Styles of Alteration Within Kaolin-Alunite Hydrothermal Deposits of Çanakkale, NW Turkey, Clay. Clay Miner., 64, 245 274, https://doi.org/10.1346/CCMN.2016.0640305, 2016.

Ferrara, R., Maserti, B. E., De Liso, A., Cioni, R., Raco, B., Taddeucci, G., Edner, H., Ragnarson, P., Svanberg, S., and Wallinder, E.: Atmospheric mercury emission at Solfatara volcano (Pozzuoli, Phlegraean Fields - Italy), Chemosphere, 29, 1421-1428, https://doi.org/10.1016/0045-6535(94)90275-5, 1994.

Fromm, P. O. and Gillette, J. R.: Effect of ambient ammonia on blood ammonia and nitrogen excretion of rainbow trout (salmo gairdneri), Comp. Biochem. Physiol., 26, 887-896, 1968.

Fitos, M., Badogiannis, E. G., Tsivilis, S. G., and Perraki, M.: Pozzolanic activity of thermally and mechanically treated kaolins of hydrothermal origin, Appl. Clay Sci., 116-117, 182-192, https://doi.org/10.1016/j.clay.2015.08.028, 2015.

Giacomelli, L. and Scandone, R.: History of the exploitation of thermo-mineral resources in Campi Flegrei and Ischia, Italy, J. Volcanol. Geoth. Res., 209-210, 19-32, 2012.

Glamoclija, M., Garrel, L., Berthon, J., and Lopez-Garcı, P.: Biosignatures and bacterial diversity in hydrothermal deposits of Solfatara Crater, Italy, Geomicrobiol. J., 21, 529-541, https://doi.org/10.1080/01490450490888235, 2004.

Gresse, M., Vandemeulebrouck, J., Byrdina, S., Chiodini, G., Revil, A., Johnson, T. C., Ricci, T., Vilardo, G., Mangiacapra, A., Lebourg, T., Grangeon, J., Bascou, P., and Metral, L.: ThreeDimensional Electrical Resistivity Tomography of the Solfatara Crater (Italy): Implication for the Multiphase Flow Structure of 
the Shallow Hydrothermal System, J. Geophys. Res.-Sol. Ea., 122, 8749-8768, https://doi.org/10.1002/2017JB014389, 2017.

Guglielminetti, M.: Mofete geothermal field, Geothermics, 15, 781790, https://doi.org/10.1016/0375-6505(86)90091-X, 1986.

Hedenquist, J. W. and Lowenstern, J. B.: The Role of Magmas in the Formation of Hydrothermal Ore Deposits, Nature, 370, 519-527, 1994.

Hedenquist, J. W., Arribas Jr., A., and Gonzales-Urien, E.: Exploration for epithermal gold deposits, Rev. Econ. Geol., 13, 245277,2000

Henley, R. D. and Ellis, A. J.: Geothermal systems ancient and modern: a geochemical review, Earth Sci. Rev., 19, 1-50, https://doi.org/10.1016/0012-8252(83)90075-2, 1983.

Holloway, J. M. and Dahlgren, R. A.: Nitrogen in rock: Occurrences and biogeochemical implications, Global Biogeochem. Cy., 16, 1118, https://doi.org/10.1029/2002GB001862, 2002.

Jaffe, D. A.: The nitrogen cycle, in: Earth system science, edited by: Jacobson, M. C., Charlson, R. J., Rohde, H., and Orians, G. H., Academic Press, San Diego, Calif, 322-342, 2000.

Lowe, S. E., Jain, M. K., and Zeikus, J. G.: Biology, ecology, and biotechnological applications of anaerobic bacteria adapted to environmental stresses in temperature, $\mathrm{pH}$, salinity, or substrates, Microbiol. Mol. Biol. R., 57, 451-509, 1993.

Madejová, J.: FTIR techniques in clay mineral studies, Vib. Spectrosc., 31, 1-10, https://doi.org/10.1016/S0924-2031(02)000656, 2003.

Madejová, J. and Komadel, P.: Baseline studies of the clay minerals society source clays: infrared methods, Clay. Clay Miner., 49, 410-432, 2001.

Madejová, J., Kečkéš, J., Pálková, H., and Komadel, P.: Identification of components in smectite/kaolinite mixtures, Clay Miner., 37, 377-388, 2002.

Martini, M., Giannini, L., Buccianti, A., Prati, F., Cellini, Legittimo, P., Iozzelli, P., and Capaccioni, B.: 1980-1990: Ten years of geochemical investigation at Phlegrean Fields (Italy), J. Volcanol. Geoth. Res., 48, 161-171, https://doi.org/10.1016/03770273(91)90040-7, 1991.

Mather, T. A., Oppenheimer, C., Allen, A. G., and McGonigle, A. J. S.: Aerosol chemistry of emissions from three contrasting volcanoes in Italy, Atmos. Environ., 38, 5637-5649, https://doi.org/10.1016/j.atmosenv.2004.06.017, 2004.

Montanaro, C., Mayer, K., Isaia, R., Gresse, M., Scheu, B., Yilmaz, T. I., Vandemeulebrouck, J., Ricci, T., and Dingwell, D. B.: Hydrothermal activity and subsoil complexity: implication for degassing processes at Solfatara crater, Campi Flegrei caldera, B. Volcanol., 79, 83, https://doi.org/10.1007/s00445-017-1167z, 2017.

Moretti, R., De Natale, G., and Troise, C.: A geochemical and geophysical reappraisal to the significance of the recent unrest at Campi Flegrei caldera (Southern Italy), Geochem. Geophy. Geosy., 18, 1244-1269, https://doi.org/10.1002/2016GC006569, 2017.

Mormone, A., Piochi, M., Troise, C., and De Natale, G.: Il laboratorio di Diffrattometria a raggi $\mathrm{X}$ dell'Osservatorio Vesuviano (Istituto Nazionale di Geofisica e Vulcanologia, Napoli): identificazione e stima quantitativa delle fasi in campioni polverizzati, Rapporti tecnici INGV, 279, 7-21, ISSN 2039-7941, 2014.

Notomista, E., Falanga, A., Fusco, S., Pirone, L., Zanfardino, A., Galdiero, S., Varcamonti, M., Pedone, E., and Contursi, P.: The identification of a novel Sulfolobus islandicus CAMP-like peptide points to archaeal microorganisms as cell factories for the production of antimicrobial molecules, Microbial. Cell. Fact., 14, 126-137, https://doi.org/10.1186/s12934-015-0302-9, 2015.

Ohmoto, H. and Rye, R. O.: Isotopes of sulfur and carbon, in: Geochemistry of Hydrothermal Ore Deposits, edited by: Barnes, H. L., Wiley, New York, 509-567, 1979.

Parafiniuk, J. and Kruszewky, L.: Minerals of the ammonioalunitammoniojarosite series e formed on a burning coal dump at Czerwionka, Upper Silesian Coal Basin, Mineral. Mag., 74, 731-745, https://doi.org/10.1180/minmag.2010.074.4.731, 2010.

Photos-Jones, E., Christidis, G. E., Piochi, M., Keane, C., Mormone, A., Balassone, G., Perdikatsis, V., and Leanord, A.: Testing Greco-Roman medicinal minerals: The case of solfataric alum, J. Archaeol. Sci. Rep., 10, 82-95, https://doi.org/10.1016/j.jasrep.2016.08.042, 2016.

Piochi, M., Bruno, P. P., and De Astis, G.: Relative roles of rifting tectonics and magma uprising processes: inferences from geophysical, structural and geochemical data of the Neapolitan volcanic region (southern Italy), Geochem. Geophy. Geosy., 6, 125, https://doi.org/10.1029/2004GC000885, 2005.

Piochi, M., Kilburn, C. R. J., Di Vito, M. A., Mormone, A., Tramelli, A., Troise, C., and De Natale, G.: The volcanic and geothermally active Campi Flegrei caldera: an integrated multidisciplinary image of its buried structure, Int. J. Earth Sci., 10, 401-421, https://doi.org/10.1007/s00531-013-0972-7, 2014.

Piochi, M., Mormone, A., Balassone, G., Strauss, H., Troise, C., and De Natale, G.: Native sulfur, sulfates and sulfides from the active Campi Flegrei volcano (southern Italy): Genetic environments and degassing dynamics revealed by mineralogy and isotope geochemistry, J. Volcanol. Geoth. Res., 304, 180-193, https://doi.org/10.1016/j.jvolgeores.2015.08.017, 2015.

Piochi, M., Mormone, A., and Balassone, G.: Hydrothermal alteration environments in the recent dynamics of the Ischia volcanic island (Southern Italy): clues from repeated field, mineralogical and geochemical surveys across the 2017 earthquake of Casamicciola, J. Volcanol. Geoth. Res., 376, 104-124, https://doi.org/10.1016/j.jvolgeores.2019.03.018, 2019.

Pirajno, F.: Hydrothermal processes and mineral systems, Springer Science \& Business Media, Geological Survey of Western Australia, 1250 pp., 2008.

Politi, J., Spadavecchia, J., Fiorentino, G., Antonucci, I., Casale, S., and De Stefano, L.: Interaction of Thermus thermophilus ArsC enzyme and gold nanoparticles naked-eye assays speciation between As(III) and As(V), Nanotechnology, 30, 26, 435703, https://doi.org/10.1088/0957-4484/26/43/435703, 2015.

Rittmann, A.: Sintesi geologica dei Campi Flegrei, Boll. Soc. Geol. Ital., 69, 117-28, 1950.

Rosi, M. and Sbrana, A.: Phlegrean Fields: Petrography, Quaderni de La Ricerca Scientifica, 114, 60-79, 1987.

Russo, M., Campostrini, I., and Demartin, F.: I minerali di origine fumarolica dei Campi Flegrei: Solfatara di Pozzuoli (Napoli) e dintorni, Periodi dell'AMI, Micro, 3, 15, 2017.

Rye, R. O.: A review of the stable-isotope geochemistry of sulfate minerals in selected igneous environments and related hydrothermal systems, Chem. Geol., 215, 5-36, https://doi.org/10.1016/j.chemgeo.2004.06.034, 2005. 
Rye, R. O., Bethke, P. M., and Wasserman, M. D.: The stable isotope geochemistry of acid sulfate alteration, Econ. Geol., 87, 225-262, https://doi.org/10.2113/gsecongeo.87.2.225, 1992.

Saccorotti, G., Petrosino, S., Bianco, F., Castellano, M., Galluzzo, D., La Rocca, M., Del Pezzo, E., Zaccarelli, L., and Cusano, P.: Seismicity associated with the 2004-2006 renewed ground uplift at Campi Flegrei Caldera, Italy, Phys. Earth Planet. In., 165, 14 24, https://doi.org/10.1016/j.pepi.2007.07.006, 2007.

Sgavetti, M., Pompilio, L., Roveri,M., Manzi, V., Valentino, G. M., Lugli, S., Carlia, C., Amici, S., Marchese, F., and Lacava, T.: Two geologic systems providing terrestrial analogues for the exploration of sulfate deposits on Mars: initial spectral characterization, Planet. Space Sci., 57, 614-627, https://doi.org/10.1016/j.pss.2008.05.010, 2008.

Sicardi, L.: La Solfatara di Pozzuoli, Bulletin Volcanologique, 18, $151-158,1959$.

Sillitoe, R. H.: Epithermal models: genetic types, geothermal controls and shallow features, in: Mineral Deposit Modeling, edited by: Kirkham, R. V., Sinclair, W. D., Thorpe, R. I., and Duke, J. M., Geological Association of Canada Special Paper, 40, 403417, 1993.

Simón, M., Martin, F., García, I., Bouza, P., Dorronsoro, C., and Auilar, J.: Interaction of limestone grains and acidic solutions from the oxidation of pyrite tailings, Environ. Pollut., 135, 6572, https://doi.org/10.1016/j.envpol.2004.10.013, 2005.

Stoffregen, R. E. and Alpers, C. N.: Observations on the unit-cell dimension, water content and $\delta \mathrm{D}$ of natural and synthetic alunite, Am. Mineral., 77, 1092-1099, 1992.

Toumi, M. and Tlili, A.: Rietveld Refinement and Vibrational Spectroscopic Study of Alunite from El Gnater, Central Tunisia, Russ. J. Inorg. Chem., 53, 1845-1853, 2008.

Valentino, G. M. and Stanzione, D.: Source processes of the thermal waters from the Phlegraean Fields (Naples, Italy) by means of the study of selected minor and trace elements distribution, Chem. Geol., 194, 245-274, https://doi.org/10.1016/S00092541(02)00196-1, 2003.
Valentino, G. M. and Stanzione, D.: Geochemical monitoring of the thermal waters of the Phlegraean Fields, J. Volcanol. Geoth. Res., 133, 261-289, https://doi.org/10.1016/S0377-0273(03)00402-5, 2004.

Valentino, G. M., Cortecci, G., Franco, E., and Stanzione, D.: Chemical and isotopic compositions of minerals and waters from the Campi Flegrei volcanic system, Naples, Italy, J. Volcanol. Geoth. Res., 91, 329344, https://doi.org/10.1016/S03770273(99)00042-6, 1999.

Vaselli, O., Tassi, F., and Tedesco, D.: Submarine and inland gas discharges from the Campi Flegrei (southern Italy) and the Pozzuoli Bay: geochemical clues for a common hydrothermal-magmatic source, Proced. Earth Plan. Sc., 4, 5773, https://doi.org/10.1016/j.proeps.2011.11.007, 2011.

Ventriglia, U.: Rilievo Geologico dei campi Flegrei, Soc. Geol. It. Bull., 69, 265-334, 1942.

Weis, D. D. and Ewing, G. E.: Infrared spectroscopic signatures of $\left(\mathrm{NH}_{4}\right)_{2} \mathrm{SO}_{4}$ aerosols, J. Geophys. Res., 101, 18709-18720, 1996.

White, N. C. and Hedenquist, J. W.: Epithermal environments and styles of mineralization: variations and their causes, and guidelines for exploration, J. Geochem. Explor., 36, 445-474, https://doi.org/10.1016/0375-6742(90)90063-G, 1990.

Zillig, W., Prangishvili, D., Schleper, C., Elferink, M., Holz, I., Albers, A., Janekovic, D., and Götz, D.: Viruses, plasmids and other genetic elements of thermophilic and hyperthermophilic Archaea, Microbiol. Rev., 18, 225-236, https://doi.org/10.1111/j.1574-6976.1996.tb00239.x, 1996.

Zotov, A., Mukhamet-Galeev, A., and Schott, J.: An experimental study of kaolinite and dickite relative stability at $150-300^{\circ} \mathrm{C}$ and the thermodynamic properties of dickite, Am. Mineral., 83, 516524, https://doi.org/10.2138/am-1998-5-610, 1998. 